\title{
Use of magnetic nanotrap particles in capturing Yersinia pestis virulence factors, nucleic acids and bacteria
}

\author{
Alexandra N. li ${ }^{1 \dagger}$, Shih-Chao Lin ${ }^{1,2 \dagger}$, Benjamin Lepene ${ }^{3}$, Weidong Zhou ${ }^{4}$, Kylene Kehn-Hall ${ }^{1,5}$ and \\ Monique L. van Hoek ${ }^{1 *}$ (D)
}

\begin{abstract}
Background: Many pathogens, including Yersinia pestis, cannot be consistently and reliably cultured from blood. New approaches are needed to facilitate the detection of proteins, nucleic acid and microorganisms in whole blood samples to improve downstream assay performance. Detection of biomarkers in whole blood is difficult due to the presence of host proteins that obscure standard detection mechanisms. Nanotrap ${ }^{\circledR}$ particles are micron-sized hydrogel structures containing a dye molecule as the affinity bait and used to detect host biomarkers, viral nucleic acids and proteins as well as some bacterial markers. Nanotraps have been shown to bind and enrich a wide variety of biomarkers and viruses in clinically relevant matrices such as urine and plasma. Our objective was to characterize the binding ability of Nanotrap particle type CN3080 to Y. pestis bacteria, bacterial proteins and nucleic acids from whole human blood in order to potentially improve detection and diagnosis.
\end{abstract}

Results: CN3080 Nanotraps bind tightly to Yersinia bacteria, even after washing, and we were able to visualize the co-localized Nanotraps and bacteria by electron microscopy. These magnetic hydrogel Nanotraps were able to bind Yersinia DNA, supporting the utility of Nanotraps for enhancing nucleic acid-based detection methods. Nanotraps were capable of increasing Y. pestis nucleic acid yield by fourfold from whole human blood compared to standard nucleic acid extraction. Interestingly, we found CN3080 Nanotraps to have a high affinity for multiple components of the Yersinia type III secretion system (T3SS), including chaperone proteins, Yop effector proteins and virulence factor protein LcrV (V). Using Nanotraps as a rapid upstream sample-prep tool, we were able to detect LcrV in human blood by western blotting with minimal blood interference in contrast to direct western blotting of blood samples in which LcrV was obscured. We were able to computationally model the interaction of LcrV with the CN3080 Nanotrap dye and found that it had a low delta-G, suggesting high affinity. Importantly, Nanotraps were also able to enhance detection of secreted Yersinia proteins by mass spectrometry.

Conclusion: Upstream use of magnetic CN3080 Nanotrap particles may improve the downstream workflow though binding and enrichment of biomarkers and speed of processing. Utilization of Nanotrap particles can improve detection of Yersinia pestis proteins and nucleic acid from whole human blood and contribute to downstream assays and diagnostics including molecular methods such as sequencing and PCR and protein-based methods.

\footnotetext{
*Correspondence: mvanhoek@gmu.edu

${ }^{\dagger}$ Alexandra N. li and Shih-Chao Lin contributed equally to this work as first authors

${ }^{1}$ School of Systems Biology, George Mason University, Manassas, VA 20110, USA

Full list of author information is available at the end of the article
}

(C) The Author(s) 2021. This article is licensed under a Creative Commons Attribution 4.0 International License, which permits use, sharing, adaptation, distribution and reproduction in any medium or format, as long as you give appropriate credit to the original author(s) and the source, provide a link to the Creative Commons licence, and indicate if changes were made. The images or other third party material in this article are included in the article's Creative Commons licence, unless indicated otherwise in a credit line to the material. If material is not included in the article's Creative Commons licence and your intended use is not permitted by statutory regulation or exceeds the permitted use, you will need to obtain permission directly from the copyright holder. To view a copy of this licence, visit http://creativeco mmons.org/licenses/by/4.0/. The Creative Commons Public Domain Dedication waiver (http://creativecommons.org/publicdomain/ zero/1.0/) applies to the data made available in this article, unless otherwise stated in a credit line to the data. 
Keywords: Yersinia pestis, DNA, Nucleic acid, Protein, Proteomics, Sample preparation, Plague, LcrV, F1 antigen, T3SS

\section{Introduction}

Yersinia (Y.) pestis is the causative agent of plague and is considered a Category A biothreat agent by the National Institute of Allergy and Infectious Diseases and classified as a select agent by the Centers for Disease Control due to its infectivity for humans [1]. This organism was responsible for the Black Death plague that decimated the population of Europe in the fourteenth century. This gram-negative bacterium has a well-characterized pathogenicity for humans and other mammals via a vector-borne life cycle involving fleas and rodents. There continue to be active zoonotic outbreaks of plague worldwide, including in the western United States and Madagascar [2, 3]. Improved and less expensive methods of detection would contribute to treating these infections, and could be enabled by Nanotrap ${ }^{\circledR}$ particles.

When humans are infected with Yersinia pestis, bacteria can be found in the blood due to initial replication followed by severe septicemia $[1,4]$, lending an opportunity for blood-based diagnostics and detection. The gold standard for diagnosing bacterial infections including plague is by culture techniques from patient blood samples; however, culturing takes multiple days to obtain results and culture results from blood are variable [5]. Thus, improving the isolation and detection of $Y$. pestis from whole blood samples addresses a major clinically relevant need. In addition, new upstream sample preparation methods to bind, concentrate and protect $Y$. pestis biomarkers (such as nucleic acids or proteins) from patient blood samples may improve the sensitivity of downstream detection, such as PCR-based or antibodybased detection methods.

Nanotrap particles are micron-sized hydrogel structures made of cross-linked $\mathrm{N}$-isopropylacrylamideacrylic acid copolymers which have been used to detect host biomarkers, viral nucleic acids and proteins as well as some bacterial markers [6-13]. Nanotrap particles contain large, planar dye molecules as affinity bait encased inside the particle produced by co-polymerization of $\mathrm{N}$-isopropylacrylamide through precipitation polymerization [14]. For this study, Reactive Red 120 dye is the incorporated bait molecule (see Fig. 1). These Nanotrap microparticles have been well characterized for their ability to bind to and enhance detection of biomarkers including human growth hormone and platelet derived growth factor $[15,16]$. One interesting aspect of these hydrogel particles and the dye bait is the "nonspecificity" of their binding; that is, unlike an antibody or a specific binding protein, we are able to use the broad binding capability of the dye bait to "sample" a wide range of proteins and other biomarkers that can bind to this bait. By altering the affinity dye bait inside the hydrogel particle, for example to Cibacron Blue, the binding profile of the particles shifts to a different spectrum of the available biomarkers [15]. This can enable the enhanced detection of low abundance biomarkers [14]. Thus, the particles can be used to sample proteins or nucleic acids from a wide variety of bacteria, viruses, cells or other biological samples. By introducing this sampling method to a complex biological matrix, such as whole blood, successful biomarker detection would have even greater clinical significance.

The CN3080 Nanotrap particles have been functionalized via decoration with magnetic microparticles $(80$ $100 \mathrm{~nm}$ ), enabling rapid sample pull-down, without the need for centrifugation, enabling possible future automation of the workflow. Other formulations of magnetic nanoparticles have previously been used for bacterial separation $[17,18]$, or bacterial protein binding though use of specific bait molecules [19], demonstrating the utility of this application.

We sought to apply this property to the detection of bacteria, proteins and also nucleic acids, to see what bacterial molecules could bind to these hydrogel particles. For example, if a Yersinia pestis protein of interest is bound to the Nanotrap hydrogel particles, it could be useful as an upstream step in a workflow used to detect the biothreat agent bacteria. If Yersinia DNA was bound to the Nanotrap, molecular diagnostic tools such as PCR can be used to specifically identify the organism. If this detection could be performed from a complex and challenging biological matrix, such as whole blood, it would have even greater clinical relevance.

These hydrogel microparticles have also been shown to bind viral nucleic acids, viral capsid and even intact viruses $[6,7,10-12]$. Recently, these particles have been functionalized via the incorporation of magnetic microparticles, enabling a much more rapid pull-down without the need for centrifugation and possibly enabling future automation of the workflow. The interactions of bacteria or bacterial biomarkers with Nanotraps have not been well-studied. Nanotraps have been shown to bind and enrich the outer membrane protein of Borrelia burgdorferi, the bacterium that causes lyme disease [9] and the lipoarabinomannan of Mycobacterium tuberculosis [20]. In this work, we characterize the ability of Nanotraps to interact with Yersinia pestis (pst-pgm-) bacteria, proteins and nucleic acids. 


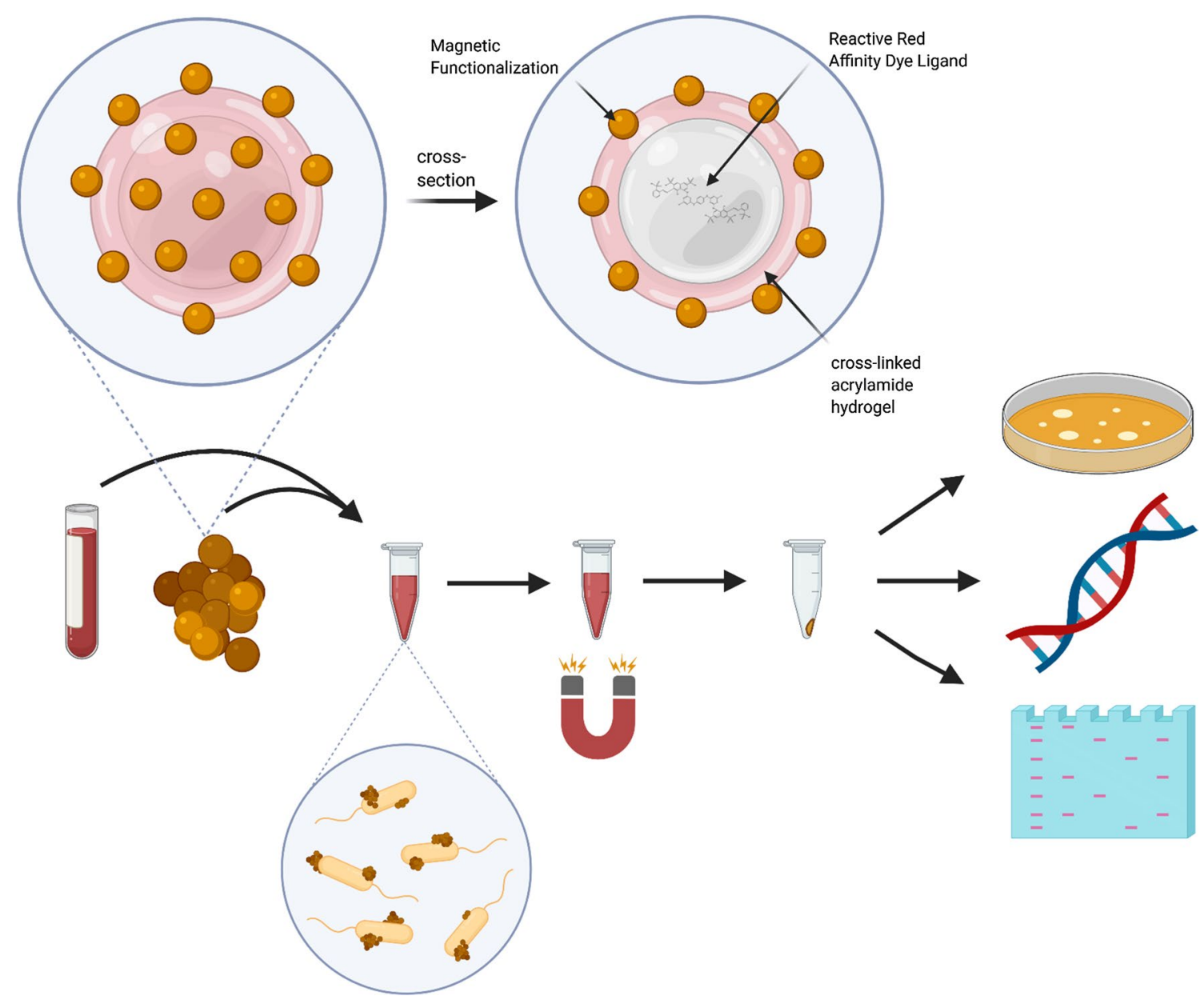

Fig. 1 Nanotrap workflow. Magnetic Nanotraps (red spheres) can be added to challenging matrices, such as blood. Nanotraps adhere to microbial proteins and nucleic acid as well as bacteria. Nanotraps are pulled down using a magnet and interfering blood can be removed and used for further analysis. The magnetic pellet can be rapidly processed through downstream applications for diagnostic purposes

\section{Materials and methods}

\section{Blood}

Pooled, mix-gender de-identified whole human blood with K2EDTA (Catalog \#: HUMANWBK2PZN) was obtained from BioIVT (www.bioivt.com).

\section{Bacteria}

The BSL2 strain Yersinia pestis pgm-pst- is a derivative avirulent strain of Yersinia pestis CO92 and was obtained from Dr. Ramin Hakami with permission of USAMRIID (RG Panchal, USAMRIID) [21-23]. This strain is pigmentation (pgm)-deficient and cured of the plasminogen-activator-encoding pPst plasmid (thus pgm-pst-) and thus is avirulent for humans, and can be safely used at Biosafety level 2 [21-23].

Bacteria were streaked onto Brain Heart Infusion agar plates from a frozen $\left(-80^{\circ} \mathrm{C}\right)$ glycerol stock and grown at $28{ }^{\circ} \mathrm{C}$. A single colony was isolated and used to inoculate Brain Heart Infusion broth (BHI) and grown for $24-36 \mathrm{~h}$ at $28{ }^{\circ} \mathrm{C}$ with shaking at $180 \mathrm{rpm}$ following published methods [24]. Cultures were enumerated using McFarland readings (Benchtop Densitometer Turbidimeter, McFarland Units, DEN-1, Grant Instruments) and verified by plating. Bacteria were pelleted and resuspended in Dulbecco's Phosphate Buffered Saline (DPBS) to a McFarland value of 0.5 (a McFarland value of 0.5 is equivalent to $1 \times 10^{7} \mathrm{CFU} / \mathrm{mL}$ for this organism).

\section{Nanotraps}

Magnetized Nanotrap ${ }^{\circledR}$ CN3080 particles from Ceres Nanoscience (www.ceresnano.com) were used. These particles contain Reactive Red 120 Dye as the chemical bait. Nanotraps were provided from Ceres either as a sterile solution of particles at $5 \mathrm{mg} / \mathrm{mL}$ in buffer, or 
as a lyophilized pellet pre-aliquoted in a tube $(0.25 \mathrm{mg}$ Nanotraps). The estimated size of these particles is $400-$ $900 \mathrm{~nm}$ decorated with 80-120 nm magnetic spheres. In order to separate magnetic Nanotraps from a solution, the GE MagRack 6 was used. The magnetic bar was placed next to the microcentrifuge tube for approximately $5 \mathrm{~min}$ in order to "pull-down" the particles.

\section{Bacterial binding to nanotraps}

Bacterial binding to Nanotraps was determined by adding $1 \times 10^{5}$ CFU bacteria to $200 \mu \mathrm{L}$ blood. $50 \mu \mathrm{L}(0.25 \mathrm{mg})$ of wet Nanotraps or $0.25 \mathrm{mg}$ lyophilized Nanotraps were added to the sample and incubated for the indicated time at the indicated temperature, or for $30 \mathrm{~min}$ if no time is indicated. Following incubation, $800 \mu \mathrm{L}$ DPBS was added to Nanotrap tubes and Nanotraps were pelleted using the magnetic bar. The supernatant was carefully removed and the pellet was washed with an additional $800 \mu \mathrm{L}$ DPBS if specified. $100 \mu \mathrm{L}$ DPBS was added to fully resuspend the Nanotrap pellet. 1:10 serial dilutions were conducted and $5 \mu \mathrm{L}$ spot dilutions were plated $(\mathrm{n}=5)$ on to Tryptic Soy Agar with 5\% sheep's blood or BHI agar plates to be enumerated after $36 \mathrm{~h}$ at $28{ }^{\circ} \mathrm{C}$. Additionally, bacteria were plated with dilutions of Nanotraps in DPBS to verify a lack of growth inhibition.

\section{Bacterial stability with nanotraps}

Bacterial stability was determined by adding $1 \times 10^{5} \mathrm{CFU}$ to whole human blood. $50 \mu \mathrm{L}$ of wet Nanotraps (or $0.25 \mathrm{mg}$ of lyophilized Nanotraps) were added to the sample and incubated for the indicated time at the indicated temperature, or for $30 \mathrm{~min}$ if no time is indicated. Following the incubation time, $10 \mu \mathrm{L}$ of the thoroughly mixed suspension were diluted into $90 \mu \mathrm{L}$ DPBS and 1:10 spot dilutions were conducted as stated.

\section{Nucleic acid preparation}

Genomic DNA (gDNA) was prepared from samples using the DNeasy UltraClean Microbial kit (Qiagen) from Yersinia bacteria grown at $28^{\circ} \mathrm{C}$ in $\mathrm{BHI}$ media. The quality of the gDNA was assessed by running on agarose gels. The quantity was determined by Nanodrop reading $260 / 280 \mathrm{~nm}$ ratio. These samples were used as positive controls for further experiments.

\section{Nucleic acid binding to nanotraps}

Nanotrap samples were processed for plating experiments such as "bacteria incubated with Nanotraps", and were then processed for nucleic acid extraction using the DNeasy UltraClean Microbial kit with the following modifications: DPBS was added 4:1 to blood Nanotrap samples. Samples were vortexed to reconstitute solidified blood and centrifuged following the kit protocol.
Supernatant was removed. Washed samples were resuspended in the same volume of DPBS, centrifuged, and supernatant was removed. The particle pellet was resuspended in $300 \mu \mathrm{L}$ PowerBead solution and Qiagen protocol was continued as instructed.

\section{Primer design and validation}

Yersinia $16 \mathrm{~s}$ rRNA primers (Thermo Fisher Scientific) 5'-AGAGTTTGATCCTGGCTCAG-3' and 5'-GGT TACCTTGTTACGACTT- $3^{\prime}$ were identified in literature [25]. qPCR was performed using primers designed against Yersinia Ferric Uptake Regulator gene (Fur):

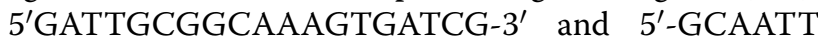
GCCGGTTTCACAGT-3'. Validation of the primers was performed by serial dilutions of $Y$. pestis CO92 DNA obtained from BEI Resources (NR-2717, Manassas, VA), alongside extracted $Y$. pestis pgm-pst-gDNA, with appropriate negative controls.

\section{PCR detection of nucleic acids}

Standard PCR was conducted using Q5 High-Fidelity $2 \times$ Mastermix (New England Biolabs) using a thermalcycler (BioRad CFX96) with the following protocol: $98^{\circ} \mathrm{C}$ for $30 \mathrm{~s}$, followed by 25 cycles of $98^{\circ} \mathrm{C}$ for $10 \mathrm{~s}, 60^{\circ} \mathrm{C}$ for $30 \mathrm{~s}$, and $72{ }^{\circ} \mathrm{C}$ for $30 \mathrm{~m}$, followed by $72{ }^{\circ} \mathrm{C}$ for $2 \mathrm{~min}$. The PCR product was run on a $1 \%$ agarose gel, stained using SYBR-Safe in TAE (Thermo Fisher Scientific), and visualized using the Bio-Rad ChemiDoc imager. $\mathrm{qPCR}$ was conducted using SYBR Green Perfecta Mastermix (Quantabio) with the following protocol: $95{ }^{\circ} \mathrm{C}$ for $60 \mathrm{~s}$, with 40 cycles of $95{ }^{\circ} \mathrm{C}$ for $5 \mathrm{~s}, 52^{\circ} \mathrm{C}$ for $15 \mathrm{~s}$, and $68^{\circ} \mathrm{C}$ for $10 \mathrm{~s}$, with plate reads at the end of each cycle (BioRad CFX96). Quantitative values were obtained based on standard curve calculations through Bio-Rad CFX96 software manager.

\section{Bacterial lysate protein binding to nanotraps}

A $24-36 \mathrm{~h}$ culture was grown at $28^{\circ} \mathrm{C}$ or $37^{\circ} \mathrm{C}$ on BHI agar or in BHI media. Plated cultures were scraped into $20 \mathrm{mM}$ Tris $\mathrm{HCl}$. Liquid cultures were centrifuged for $6000 \times g$ for $10 \mathrm{~m}$, then the bacterial pellet was resuspended in cold $20 \mathrm{mM}$ Tris $\mathrm{HCl}$. Cells were sonicated on ice using the QSonica for $30 \mathrm{~s}$ at $40 \%$ amplitude, followed by $30 \mathrm{~s}$ pauses for 10 cycles, or until turbidity dissipated. Whole cell lysate (WCL) was centrifuged for $12,000 \times g$ for $15 \mathrm{~m}$, then the supernatant was filtered using a $0.22 \mu \mathrm{m}$ filter. Protein concentration was measured, then the cell lysate was aliquoted and stored at $-80{ }^{\circ} \mathrm{C}$ until further use. Liquid or lyophilized CN3080 Nanotraps were resuspended in $200 \mu \mathrm{L}$ cell lysate at a known concentration, diluted in DPBS. Samples were incubated with mixing at room temperature for $30 \mathrm{~m}$ or $2 \mathrm{~h}$, respectively. $800 \mu \mathrm{L}$ DPBS was added prior to pelleting on a 
magnetic rack. Supernatant was discarded. If specified as washed, the CN3080 Nanotrap pellet was fully resuspended off the magnetic rack in $800 \mu \mathrm{L}$ DPBS, pelleted, and supernatant was discarded.

\section{Secreted protein binding}

The supernatant (BHI) of a $37{ }^{\circ} \mathrm{C}$ grown culture was removed following centrifugation and filtered through a $0.22 \mu \mathrm{m}$ filter. Filtration product containing secreted proteins was diluted in DPBS or 1:4 whole human blood: DPBS. $1 \mathrm{~mL}$ of sample was added per tube of lyophilized particles. Additionally, larger volumes of culture supernatant were tested using the same ratio of $1 \mathrm{~mL}$ per tube of lyophilized particles $(0.75 \mathrm{mg}$ Nanotraps per $3 \mathrm{~mL}$ undiluted supernatant).

\section{Intact whole cell binding}

A $24-36$ h culture of $Y$. pestis was grown at $28{ }^{\circ} \mathrm{C}$ or $37^{\circ} \mathrm{C}$, centrifuged for $6000 \times g$ for $10 \mathrm{~m}$ and resuspended to 0.5 McFarland. $0.25 \mathrm{mg}$ Nanotraps were resuspended in $1 \times 10^{7} \mathrm{CFU} / \mathrm{mL}$ and mixed at room temperature for 2 h. $800 \mathrm{uL}$ DPBS was added prior to pelleting on magnetic rack. Supernatant was discarded.

\section{Mass spectrometry method}

After pelleting on a magnetic rack and aspirating supernatant, Nanotrap samples were mixed with $20 \mu \mathrm{L}$ of $8 \mathrm{M}$ urea and incubated at $50{ }^{\circ} \mathrm{C}$ for $2 \mathrm{~min}$. After centrifugation, the supernatant was reduced with $10 \mathrm{mM}$ DTT, alkylated with $50 \mathrm{mM}$ iodoacetamide, and digested with trypsin for $2 \mathrm{~h}$ at $37^{\circ} \mathrm{C}$. The digestion mixture was desalted with ZipTip, dried in SpeedVac, then reconstituted with $10 \mu \mathrm{L}$ of $0.1 \%$ formic acid. LC-MS/MS experiments were performed on an Orbitrap Fusion (ThermoFisher Scientific, Waltham, MA, USA) equipped with a nanospray EASY-nLC 1200 HPLC system. Peptides were separated using a reversed-phase PepMap RSLC $75 \mu \mathrm{m}$ i.d. $\times 15 \mathrm{~cm}$ long with $2 \mu \mathrm{m}, \mathrm{C} 18$ resin LC column. The mobile phase consisted of $0.1 \%$ aqueous formic acid (mobile phase A) and $0.1 \%$ formic acid in $80 \%$ acetonitrile (mobile phase B). After sample injection, the peptides were eluted by using a linear gradient from 5 to $40 \% \mathrm{~B}$ over $60 \mathrm{~min}$ and ramping to $100 \% \mathrm{~B}$ for an additional $2 \mathrm{~min}$. The flow rate was set at $300 \mathrm{~nL} / \mathrm{min}$. The Orbitrap Fusion was operated in a data-dependent mode in which one full MS scan (60,000 resolving power) from 300 to $1500 \mathrm{Da}$ using quadrupole isolation, was followed by MS/MS scans in which the most abundant molecular ions were dynamically selected by Top Speed, and fragmented by collision-induced dissociation (CID) using a normalized collision energy of 35\%. "Peptide Monoisotopic Precursor Selection" and "Dynamic Exclusion" (10 s duration), were enabled, as was the charge state dependency so that only peptide precursors with charge states from +2 to +4 were selected and fragmented by CID. Tandem mass spectra were searched against the NCBI Yersinia pestis database (ASM906.1) using Proteome Discover version 2.1. Mass tolerance for precursor ions was $2 \mathrm{ppm}$, and mass tolerance for fragment ions was $0.5 \mathrm{Da}$. Data were analyzed with oxidation $(+15.9949 \mathrm{Da})$ on methionine as a variable modifications, and carbamidomethyl cysteine $(+57.0215)$ as a fixed modification. A $1 \%$ false discovery rate (FDR) was used as a cut-off value for reporting peptide spectrum matches (PSM) from the database.

\section{Relative enrichment value of Yersinia proteins bound to CN3080 nanotraps}

The number of peptide spectra matches (PSMs) for each protein (including one hits) within a sample was summed, giving the total number of PSMs within a MS sample. For each protein, the individual number of PSMs was divided by the total number of PSMs within the sample. This process was conducted for all MS samples. The enrichment value was determined through normalization by dividing the number PSM/total PSM for a Nanotrap sample with the PSM/total PSM with its respective control. Relative Enrichment values comparing whole cell Nanotrap and lysate Nanotrap samples were also calculated. A PSM value of 5 in either the Nanotrap or control sample was set as the minimum to be considered for enrichment calculation.

\section{Western blot method}

Following incubation, Nanotraps were pelleted on magnetic rack and supernatant was removed. Pellets were resuspended in $50 \mu \mathrm{L}$ SDS sample buffer (ThermoFisher). Proteins were denatured and eluted from Nanotraps by heating at $90{ }^{\circ} \mathrm{C}$ for $10 \mathrm{~m}$, pelleting on magnetic rack, and loading $15 \mu \mathrm{L}$ onto a $4-12 \%$ Bis Tris Protein gel. Samples were run at $200 \mathrm{~V}$ for $32 \mathrm{~min}$, transferred onto PVDF membrane, and blocked in TSB-T 5\% nonfat milk solution for $1 \mathrm{~h}$. Membranes were probed overnight at $4{ }^{\circ} \mathrm{C}$ with a 1:50 LcrV (V-antigen, BEI NR-3831) or 1:50 F1 antigen antibody (Invitrogen MA1-7427) in TSB-T nonfat milk following the manufacturers suggestion. Secondary probing was conducted with 1:1000 anti-goat (R\&D HAF017) or goat anti-mouse antibodies (Invitrogen $\# 31,430)$ and bands were visualized using West Femto chemiluminescent solution and imaging on a ChemiDoc instrument (Bio-Rad).

\section{Scanning electron microscopy method}

Standard methods were used to prepare and visualize bacterial samples [26]. Briefly, bacteria were grown at $28{ }^{\circ} \mathrm{C}$ for $24-36 \mathrm{~h}$ in $\mathrm{BHI}$, centrifuged at $6000 \times g$ for 
$10 \mathrm{~m}$, and resuspended to $0.5 \mathrm{McF}$ arland in DPBS. $1 \mathrm{~mL}$ of resuspension was bound to lyophilized CN3080 Nanotraps following standard unlysed bacteria binding protocol, with variations of bacterial concentrations. Samples were fixed for $30 \mathrm{~min}$ with a $5 \%$ glutaraldehyde solution in $0.1 \mathrm{M}$ phosphate buffer (pH 7.2). Fixative was discarded and the Nanotrap pellet was washed twice with $0.1 \mathrm{M}$ phosphate buffer. Following carbon coating, fixed cells and Nanotraps were visualized using the Hitachi SU-70 Schottky field emission gun scanning electron microscope at University of Maryland's Advanced Imaging \& Microscopy Laboratory (College Park, MD).

\section{Protein docking prediction}

The protein structures of $Y$. pestis virulence factors PsaA and LcrV were directly downloaded from PDB (entries: 4F8P, 4JBU) and the chemical structure of Reactive Red 120 was retrieved from ChemSpider (http://www.chems pider.com). Structures were subsequently submitted to SwissDock for evaluating potential docking pockets by Native Binding Mode (NBM). The docking results were visualized with UCSF Chimera v1.13 in the space-filling model presenting the electrostatic potential surface according to Coulomb's law. The lowest free energy predicted by SwissDock would be considered as the strongest binding interaction between Reactive Red 120 and PsaA or LcrV (Fig. 6a, b).

\section{Statistics and data analysis}

Comparisons between Nanotrap and control samples were conducted using unpaired Student's T-tests using GraphPad Prism software. Statistical significance was set at $\mathrm{P}<0.05$. Gene ontology was analyzed by PANTHER Overrepresentation Test (Released 20190711, GO Ontology database Released 2019-12-09) analyzed against the Yersinia pestis reference list.

\section{Availability of data and materials}

The datasets supporting the conclusions of this article are included within the article and its additional files.

\section{Results}

As part of a larger project to characterize the capabilities of a panel of Nanotraps, we previously screened a panel of available Nanotrap particles (Ceres Nanoscience) made with various dye cores, in both magnetic and non-magnetic formulations in order to identify a particle formulation that bound well to both bacterial and viral markers [12]. The formulation of Nanotrap (Particle type CN3080) that was chosen for further characterization was a magnetic version of the Nanotrap particle containing Reactive Red 120 dye. This particle type was selected for its ability to bind both to viral markers [12] as well as bacterial proteins. Here, we characterize the ability of CN3080 Nanotrap particles to interact with Yersinia pestis (pst-pgm-) bacteria, its proteins and nucleic acids.

The workflow for using Nanotrap particles is illustrated in Fig. 1. These hydrogel microparticles are magnetized to provide easy and rapid particle separation without centrifugation. The particles are added to the complex biological matrix such as blood or plasma and allowed to bind between $30 \mathrm{~min}$ and $2 \mathrm{~h}$ with rotation. The particles are then pelleted by magnetic pull-down, allowing for simplified target separation from technically challenging matrices like blood. Target products, such as viable bacteria, nucleic acid, and protein, can be eluted from the particles for downstream processing.

\section{CN3080 Nanotraps bind Yersinia bacteria visualized by electron microscopy}

We were able to observe the bacteria with Nanotrap particles by electron microscopy. The CN3080 Nanotraps are estimated to be $400-800 \mathrm{~nm}$ with magnetic spheres of approximately $80-120 \mathrm{~nm}$ in size decorating the surface, which can be seen in the figure (Fig. 2a). Yersinia pestis bacteria is estimated to be $1-3 \mu \mathrm{m}$ long and $0.5-0.8 \mu \mathrm{m}$ wide (Fig. 2b). As seen in panels $2 \mathrm{C}$ and 2D (Fig. 2c, d), the bacteria and Nanotraps appear to associate with each other on the surface of the bacteria when incubated together in PBS buffer.

\section{CN3080 Nanotraps bind Yersinia bacteria from whole human blood}

We found that the $Y$. pestis bacteria associate tightly with the Nanotrap particles in whole human blood, even after washing (Fig. 3a). In this experiment, $7 \times 10^{4} \mathrm{CFU}$ were found associated with the Nanotraps after the first pull-down, and following subsequent washing steps, $1 \times 10^{4} \mathrm{CFU}$ were found to be still attached to the particles. No significant inhibition of bacterial growth was found with increased concentrations of Nanotraps up to $100 \mathrm{uL} / \mathrm{mL}$ (Additional file 1: Figure S1).

CN3080 Nanotrap particles have an affinity for Yersinia pestis bacteria in undiluted whole human blood. Binding experiments show consistent bacterial recovery following 2 PBS washes. However, the addition of the Nanotrap particles to blood containing bacteria did not appear to increase stability of bacteria at elevated temperatures (Additional file 1: Figure S2, S3). Though Nanotraps were capable of binding and pulling bacteria out of solution, the rate of CFU decline was not improved, thus we conclude that the Nanotraps do not "stabilize" the bacteria.

Although Nanotrap particles do not enhance bacterial stability over time and at elevated temperatures, they do associate tightly with bacteria. In the experiment shown in Fig. $3 \mathrm{~b}, 1 \times 10^{5} \mathrm{CFU}$ were spiked into 

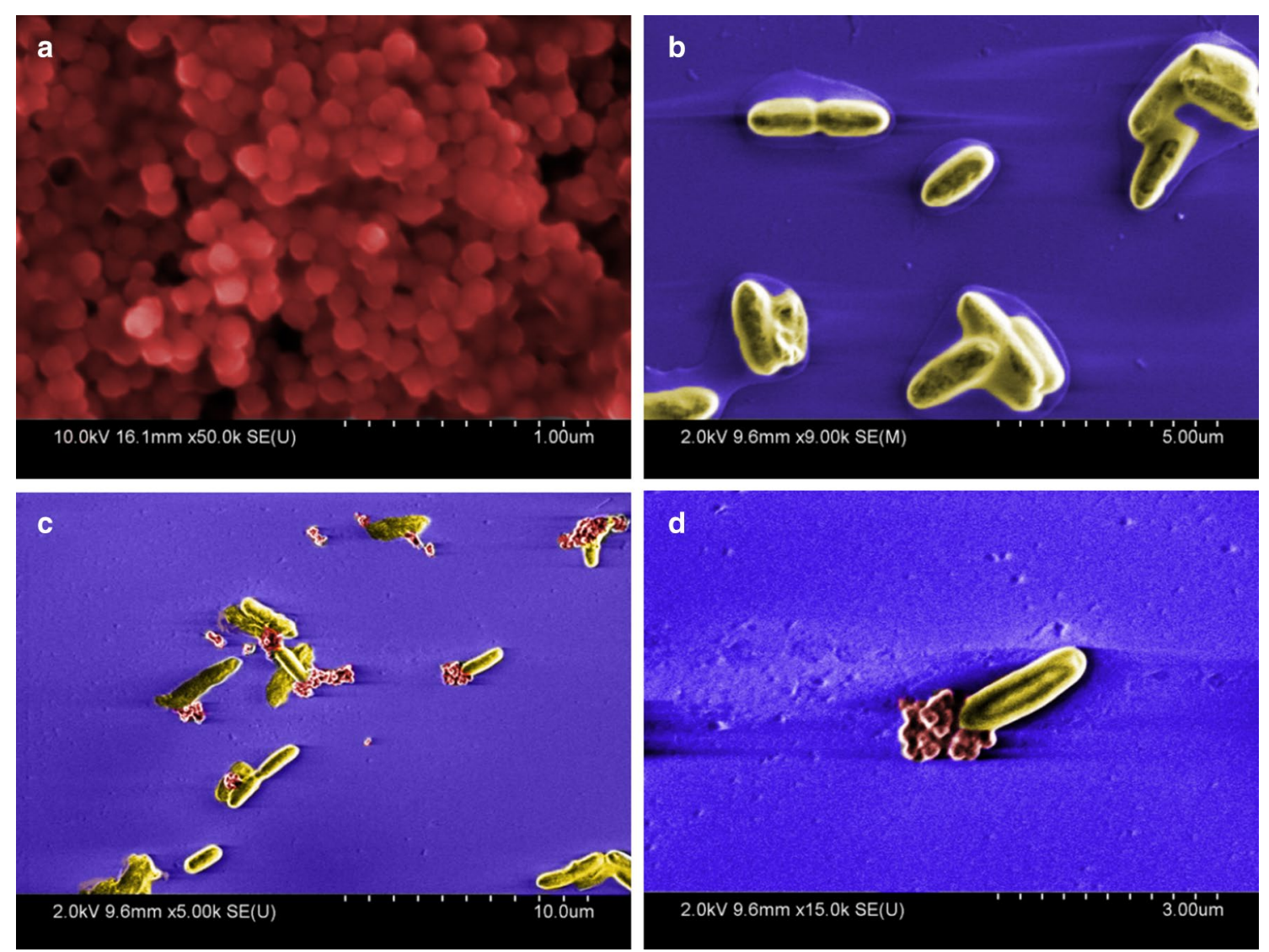

Fig. 2 Scanning electron microscopy images of Yersinia pestis bacteria associated with CN3080 Nanotraps. a CN3080 Nanotraps (1 $\mu$ m scale) without bacteria), b Yersinia bacteria without Nanotraps ( $5 \mu \mathrm{m}$ scale), c, d Yersinia fixed following $2 \mathrm{~h}$ incubation with Nanotraps (10 and $3 \mu \mathrm{m}$ scales)
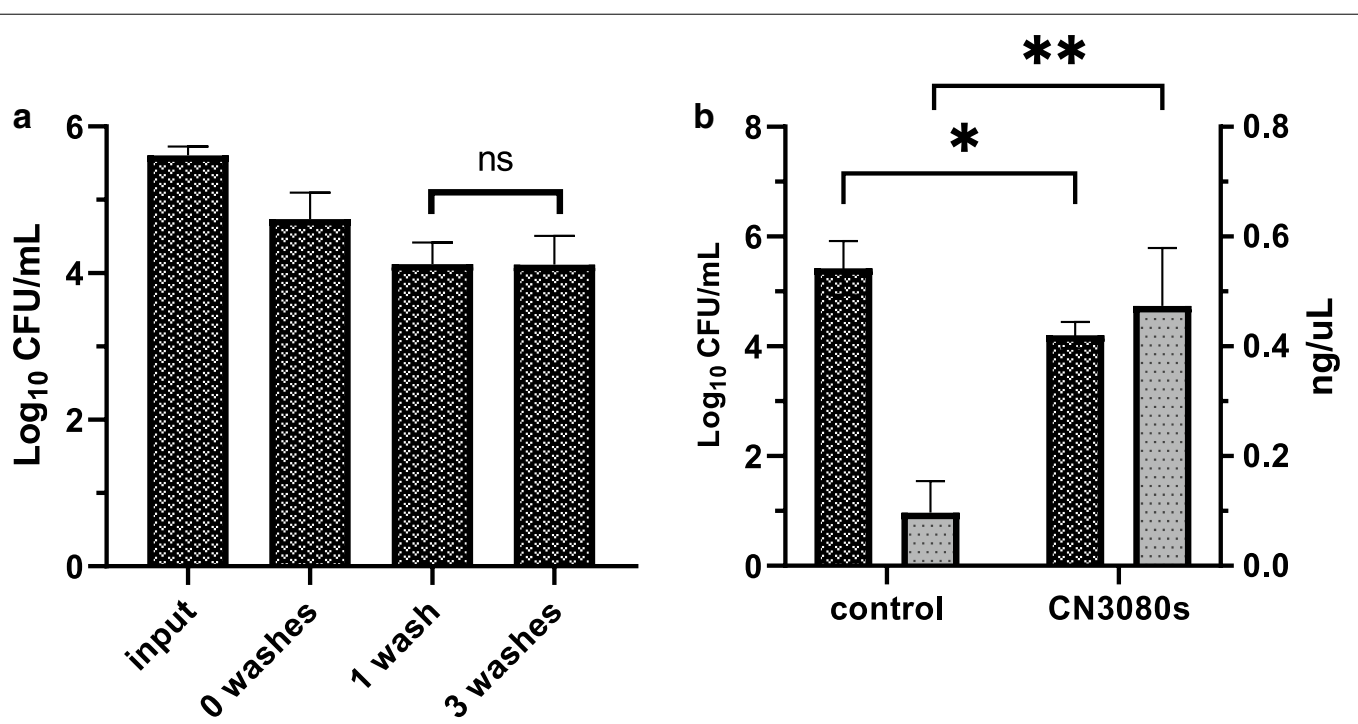

Fig. 3 CN3080 Nanotraps bind Yersinia bacteria and enhance nucleic acid yield. a Following bacterial binding to CN3080s, bacteria were pulled down by magnetic rack and plated. The magnetic pellet was washed 1 or 3 times and plated to calculated CFU/mL. No significant decrease in CFU/ $\mathrm{mL}$ was determined with repeated washes. b Following overnight incubation at $40^{\circ} \mathrm{C}$ with CN3080s, a significant $(P<0.05)$ decrease in CFU was found relative to without CN3080s. Nucleic acid yield was significantly improved $(P<0.005)$ with use of CN3080s 
$200 \mu \mathrm{L}$ whole human blood and incubated at $40{ }^{\circ} \mathrm{C}$ for $24 \mathrm{~h}$ to promote release of nucleic acid while allowing some cell survival (Fig. 3b). CN3080 Nanotraps were pelleted from blood by centrifugation at $6000 \times g$, resuspended, and plated. Centrifugation of the samples allowed detection of unbound bacteria. Control and Nanotrap samples were plated following incubation to determine the impact of Nanotraps and/or elevated temperature on bacterial survival. We found a significant decrease $(20 \%)$ in viable bacteria $(\mathrm{P}<0.05)$ when incubated at $40{ }^{\circ} \mathrm{C}$ for $24 \mathrm{~h}$, indicating that Nanotraps do not stabilize Yersinia pestis against this elevated temperature.

\section{CN3080 Nanotraps facilitate nucleic acid extraction}

We have been able to demonstrate binding of Yersinia pestis (pgm-pst-) genomic DNA from whole human blood spiked with $20 \mathrm{ng}$ bacterial gDNA (Additional file 1: Figure S4). CN3080 Nanotraps were capable of enhancing detection of $Y$. pestis gDNA from whole human blood stored at $40{ }^{\circ} \mathrm{C}$ for $48 \mathrm{~h}$. Though this does not establish increased temperature stability of Yersinia gDNA with the addition of Nanotraps, it does suggest that Nanotraps are capable of associating with bacterial nucleic acid and improving overall yield. The same CN3080 Nanotraps have been shown to bind Venezuelan Equine Encephalitis Virus nucleic acid in blood [12].

In the same experiment, shown in Fig. 3b, $1 \times 10^{5}$ CFU were spiked into $200 \mu \mathrm{L}$ whole human blood and incubated at $40{ }^{\circ} \mathrm{C}$ for $24 \mathrm{~h}$ to promote release of nucleic acid from the death of some bacteria at this elevated temperature. CN3080 Nanotraps were pelleted from blood by centrifugation at $6000 \times g$, resuspended (and plated, see above), then nucleic acid was extracted from the remaining sample. Despite a significant decrease in viable bacteria $(\mathrm{P}<0.05)$, we found significant improvement in nucleic acid yield using CN3080 Nanotraps $(\mathrm{P}<0.005)$. These data further support the utility of Nanotraps for enhancing DNA detection.

\section{Nanotraps enhance detection of virulence factors by Mass-spectrometry}

We conducted experiments to assess the ability of Nanotraps to bind and enrich $Y$. pestis proteins under a variety of growth conditions, including varied temperatures and media (Table 1, Samples 1-6 described). Additionally, from $37{ }^{\circ} \mathrm{C}$ grown $Y$. pestis, we examined the affinity of Nanotraps for intra- and extracellular proteins by binding to both un-lysed cells and whole cell lysate (WCL). We found that Nanotrap particles are capable of enhancing detection of Yersinia proteins from both $28{ }^{\circ} \mathrm{C}$ and $37{ }^{\circ} \mathrm{C}$ growth conditions, reflecting the temperature of both environmental and clinical samples respectively (Fig. 4). The use of CN3080 Nanotraps resulted in successful recovery of approximately 70-90\% proteins found in respective whole-cell lysate (control) samples (Additional files 2, 3, 4, 5, 6, 7: Tables S1-S6). Within Sample S1 $\left(28{ }^{\circ} \mathrm{C}\right.$ grown whole cell lysate incubated with Nanotraps), we found that approximately $70 \%$ of the total proteins detected in whole cell lysate were identified on Nanotraps (Fig. 4a), similarly for the bacteria grown at $37{ }^{\circ} \mathrm{C}$ (Fig. 4b). For 258 of these proteins, we found a concentrating effect where the number of identified peptides (as \#PSM) was greater within the Nanotrap sample (Additional Tables). However, no significant relationship was found between these proteins (Additional file 1: Figure S6). Although CN3080 Nanotraps did not recover all proteins found in the whole cell lysate samples, we found approximately $60 \%$ of these proteins present in other CN3080 samples, suggesting that the results are not due to a lack of affinity and occur due to sample variability.

Yersinia genes on the pCD1 plasmid, specifically those encoding the type III secretion system are known to be upregulated at $37{ }^{\circ} \mathrm{C}$, while low levels of these proteins are produced at $28{ }^{\circ} \mathrm{C}$ [27]. Within our $28{ }^{\circ} \mathrm{C}$ sample set, we identified many of these proteins with greater numbers of peptide spectra counts compared those found in the respective control sample (Y0075, ParD, LcrG, YopN, YscE, YscM, Caf1A). Specifically, LcrG, YPMT1.69, YPMT1.71, and YPMT1.68A could not be found in $28{ }^{\circ} \mathrm{C}$ samples without CN3080 Nanotraps. This result is representative of the Nanotrap's ability to

Table 1 Sample identification key for Fig. 7 Yersinia pestis samples submitted for mass spectrometry

\begin{tabular}{|c|c|}
\hline Sample name & Sample description \\
\hline W28A & WCL of $28^{\circ} \mathrm{C}$ agar plate grown Y. pestis bound to $0.25 \mathrm{mg}$ CN3080s \\
\hline W37A & WCL of $37^{\circ} \mathrm{C}$ agar plate grown Y. pestis bound to $0.25 \mathrm{mg}$ CN3080s \\
\hline W37B, & WCL of $37^{\circ} \mathrm{C}$ broth grown Y. pestis bound to $0.25 \mathrm{mg}$ CN3080s \\
\hline W37BW & $\begin{array}{l}\text { WCL of } 37^{\circ} \mathrm{C} \text { broth grown Y. pestis bound to } 0.25 \mathrm{mg} \text { CN3080s, } \\
\text { washed with DPBS }\end{array}$ \\
\hline U37 & Unlysed $37^{\circ} \mathrm{C}$ broth grown Y.pestis bound to $0.25 \mathrm{mg}$ CN3080s \\
\hline S37 & Y. pestis Supernatant (secreted proteins) bound to $0.25 \mathrm{mg}$ CN3080s \\
\hline
\end{tabular}



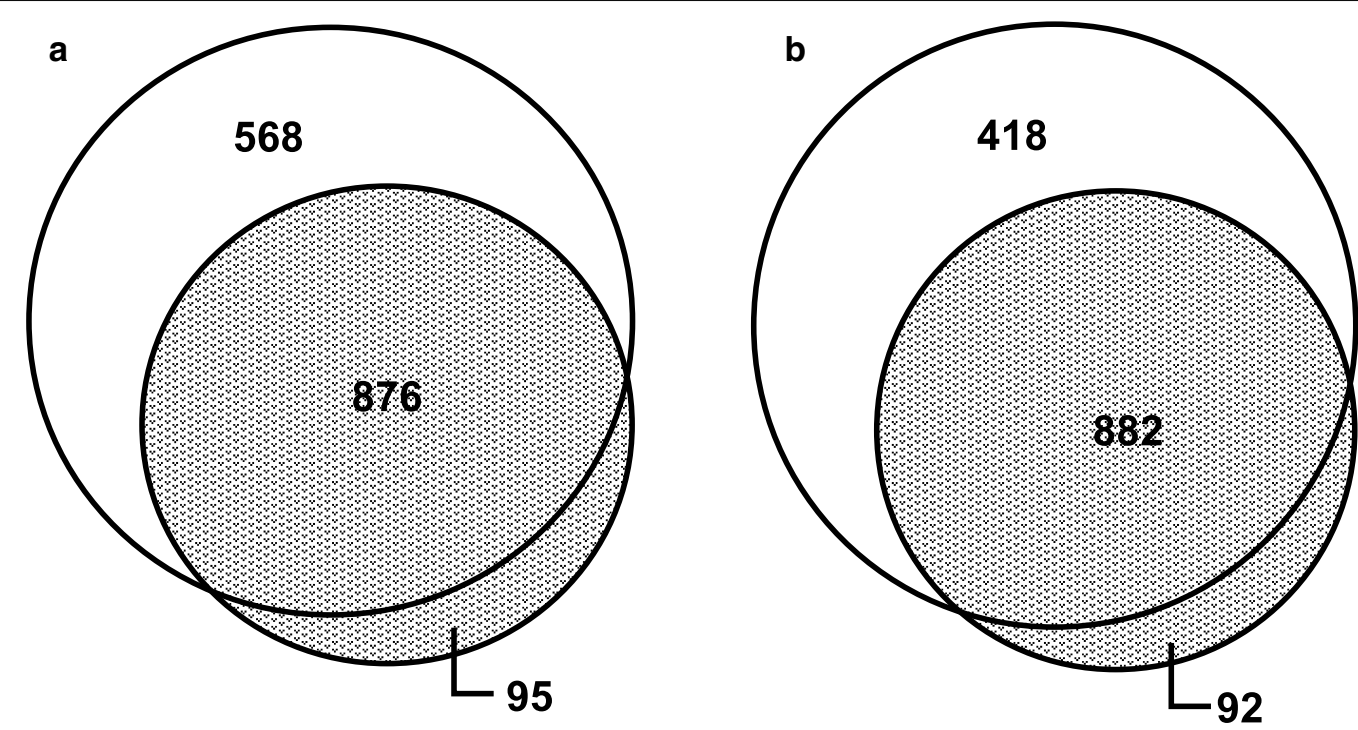

Fig. $4 \mathrm{CN} 3080$ Nanotraps bind both $28^{\circ} \mathrm{C}$ and $37^{\circ} \mathrm{C}$ expressed Yersinia proteins. Venn diagrams of Yersinia proteins found by mass spectrometry. a Total proteins found from $28^{\circ} \mathrm{C}$ grown Yersinia control samples (light grey) and proteins found bound to CN3080s (dots) following incubation with $28^{\circ} \mathrm{C}$ grown bacterial proteins. b Total proteins found from $37^{\circ} \mathrm{C}$ grown controls (dark grey) and proteins found bound to CN3080s (dots) following incubation with $37^{\circ} \mathrm{C}$ grown proteins

concentrate low-level proteins and allow detection by mass spectrometry.

When sorted by the number of PSMs, the top $37^{\circ} \mathrm{C}$ expressed proteins pulled down by CN3080 Nanotraps are predominantly enzymes and chaperone proteins (Table 2, Additional file 3: Tables S2, Additional file 4: Table S3, Additional file 5: Table S4). Within the top 20 proteins found in CN3080 Nanotrap samples, $20 \%$ of proteins are involved in protein folding, including isomerase
FkpA and chaperone proteins Tig, DnaK, GroL, and ClpB. The top 20 most abundant proteins found in Nanotrap samples can also be found within the top $10 \%$ of respective controls, indicating protein abundance plays a role in CN3080 Nanotrap binding. However, some frequently occurring proteins possess higher numbers of PSMs in Nanotrap samples compared to control samples; these proteins include KatG, DnaK and Acs, which are consistently found enriched in whole cell lysate of $37^{\circ} \mathrm{C}$

Table 2 Top 5 proteins bound to CN3080 Nanotraps found by Mass Spectrometry found in $37^{\circ} \mathrm{C}$-grown Yersinia pestis samples (Whole Cell Lysate samples W37A, W37B, and W37BW (agar grown, broth-brown and broth-grown and washed Nanotraps, respectively), and unlysed bacteria Sample 5)

\begin{tabular}{|c|c|c|c|c|c|}
\hline Entry & Gene names & Mass (kDa) & $\begin{array}{l}\text { Gene ontology (biological } \\
\text { process) }\end{array}$ & $\begin{array}{l}\text { Gene ontology (cellular } \\
\text { component) }\end{array}$ & $\begin{array}{l}\text { Gene ontology (molecular } \\
\text { function) }\end{array}$ \\
\hline Q8ZIY3 & groL & 57.4 & $\begin{array}{l}\text { 'De novo' protein folding; protein } \\
\text { refolding }\end{array}$ & GroEL-GroES complex & $\begin{array}{l}\text { ATP binding; unfolded protein } \\
\text { binding }\end{array}$ \\
\hline Q8ZJB2 & tufA & 43.2 & Translational elongation & Cytoplasm & $\begin{array}{l}\text { GTPase activity; GTP binding; trans- } \\
\text { lation elongation factor activity }\end{array}$ \\
\hline Q9X6B0 & katG & 81.4 & $\begin{array}{l}\text { Cellular response to hydrogen } \\
\text { peroxide; hydrogen peroxide } \\
\text { catabolic process }\end{array}$ & Cytosol; periplasmic space & $\begin{array}{l}\text { Catalase activity; heme binding; } \\
\text { metal ion binding }\end{array}$ \\
\hline Q8ZAN8 & tufB & 43.2 & Translational elongation & Cytoplasm & $\begin{array}{l}\text { GTPase activity; GTP binding; trans- } \\
\text { lation elongation factor activity }\end{array}$ \\
\hline Q8ZIM7 & dnak & 69.0 & $\begin{array}{l}\text { Cellular response to heat; cellular } \\
\text { response to unfolded protein; } \\
\text { chaperone cofactor-dependent } \\
\text { protein refolding; protein refold- } \\
\text { ing; response to unfolded protein }\end{array}$ & Cytoplasm; cytosol & $\begin{array}{l}\text { ATPase activity; ATPase activ- } \\
\text { ity, coupled; ATP binding; heat } \\
\text { shock protein binding; misfolded } \\
\text { protein binding; protein folding } \\
\text { chaperone; unfolded protein } \\
\text { binding }\end{array}$ \\
\hline
\end{tabular}


grown whole-cell lysate samples of $Y$. pestis bound to CN3080s (From Table 1, Samples W37A (agar-grown), W37B, and W37BW (broth-grown with Nanotraps, with and without washing), suggesting protein structure can influence binding and enrichment level.

To determine if CN3080 Nanotraps could concentrate Yersinia pestis proteins from dilute samples, bacterial supernatant containing secreted proteins was incubated with CN3080 Nanotraps overnight at $4{ }^{\circ} \mathrm{C}$. We found that the addition of CN3080 Nanotraps enabled detection of secreted and membrane proteins by mass spectrometry (Table 3, Additional file 7: Table S6). This allowed detection of proteins from a low concentration supernatant sample without use of dialysis or standard protein concentrators. Proteins in this sample included virulence markers YopM, LcrV, and F1-antigen (caf1). In laboratory diagnosis, the F1 antigen is commonly used as a target for immunological-tests to detect $Y$. pestis [1]. thus, this result suggest that Nanotraps could potentially enhance the detection of F1 antigen in those tests. LcrV is a wellstudied, secreted protein of $Y$. pestis [28, 29]. We were able to detect Nanotrap-associated LcrV through massspectrometry proteomics analysis. The spectra from that analysis are shown in Additional file 1: Figure S7, confirming the identification of this protein in association with CN3080 Nanotraps.

Relative enrichment scores for proteins identified by mass-spectrometry were calculated by taking a samples' normalized PSMs divided by normalized PSMs of its respective control. This score is indicative of the change in individual protein concentration in the sample. Proteins with enrichment scores $\geq 2.0$ in $37{ }^{\circ} \mathrm{C}$ grown whole cell lysate (WCL) samples were assessed by gene ontology (Panther) and showed clustering based on biological process and molecular function (Additional file 8: Table S7). All established protein stabilization proteins were found within this data set including chaperone protein SurA and small heat shock proteins IbpA and IbpB $(\mathrm{P}<0.005)$. Additionally, these proteins often exhibited oxioreductase, activity, ligase activity, and cyclic or heterocyclic compound binding $(\mathrm{P}<0.0005)$. Similarly, within other $37^{\circ} \mathrm{C}$ samples analyzed by mass spectrometry, we found additional proteins with similar biological processes. Within top enrichment scores of Sample W37BW $\left(37^{\circ} \mathrm{C}\right.$ Broth-grown Y. pestis whole cell lysate with washed Nanotraps, Table 1), we identified a significant cluster of protein folding proteins such as chaperone proteins $\mathrm{ClpB}$, DnaK, HtpG, along with trigger factor Tig and enzyme FkpA $(\mathrm{P}<0.0005)$, alongside the protein stabilization proteins found on Nanotraps incubated with the whole-cell lysate of $37^{\circ} \mathrm{C}$ agar-grown Y. pestis sample (Sample W37A, Table 1).

Table 3 Membrane and secreted proteins concentrated from $37^{\circ} \mathrm{C}$ Yersinia supernatant by CN3080 Nanotraps. All listed proteins were undetected by MS without CN3080s

\begin{tabular}{|c|c|c|c|c|}
\hline Entry & $\begin{array}{l}\text { Gene names } \\
\text { (primary) }\end{array}$ & Gene ontology (biological process) & Gene ontology (cellular component) & Gene ontology (molecular function) \\
\hline P17778 & yopM & - & $\begin{array}{l}\text { Cell outer membrane; extracellular } \\
\text { region }\end{array}$ & Metal ion binding \\
\hline Q0WG31 & gptB & $\begin{array}{l}\text { Phosphoenol-pyruvate-dependent } \\
\text { sugar phosphor-transferase system }\end{array}$ & $\begin{array}{l}\text { Cytoplasm; integral component of } \\
\text { membrane }\end{array}$ & $\begin{array}{l}\text { D-glucosamine PTS permease activity; } \\
\text { protein-N(PI)-phosphohistidine-sugar } \\
\text { phosphotransferase activity }\end{array}$ \\
\hline Q7CGH2 & hasF & & Efflux pump complex; outer membrane & $\begin{array}{l}\text { Efflux transmembrane transporter } \\
\text { activity; porin activity }\end{array}$ \\
\hline POC7U7 & $\mathrm{IcrV}^{*}$ & Pathogenesis & Extracellular region & - \\
\hline Q8ZC05 & Gpt & GMP salvage; IMP salvage; XMP salvage & Cytosol; plasma membrane & $\begin{array}{l}\text { Hypoxanthine phosphoribosyltrans- } \\
\text { ferase activity; magnesium ion bind- } \\
\text { ing; xanthine phosphoribosyltrans- } \\
\text { ferase activity }\end{array}$ \\
\hline P26948 & $\operatorname{caf1}^{*}$ & & Capsule; extracellular region & \\
\hline Q8ZG77 & ompA & Ion transport & Cell outer membrane; pore complex & porin activity \\
\hline Q8ZH58 & bamA & $\begin{array}{l}\text { Gram-negative-bacterium-type cell } \\
\text { outer membrane assembly; protein } \\
\text { insertion into membrane }\end{array}$ & $\begin{array}{l}\text { Bam protein complex; integral compo- } \\
\text { nent of membrane }\end{array}$ & - \\
\hline Q8ZBN2 & eno & Glycolytic process & $\begin{array}{l}\text { Cell surface; extracellular region; phos- } \\
\text { phopyruvate hydratase complex }\end{array}$ & $\begin{array}{l}\text { Magnesium ion binding; phosphopyru- } \\
\text { vate hydratase activity }\end{array}$ \\
\hline P31493 & yopE & $\begin{array}{l}\text { Negative regulation of phagocytosis; } \\
\text { pathogenesis }\end{array}$ & Cell outer membrane & GTPase activator activity \\
\hline
\end{tabular}

* Proteins were chosen for computational modeling with dye, along with PsaA 


\section{CN3080 Nanotraps improve western blotting of LcrV protein in human blood}

Given that both F1 and LcrV protein were detected in our mass spectrometry analysis, experiments were performed to confirm these results through western blot analysis. The F1 protein is a secreted $15 \mathrm{kDa}$ protein of Yersinia pestis with a well-known role in inhibition of phagocytosis [30]. The LcrV protein is a secreted $37 \mathrm{kDa}$ protein of Yersinia pestis that acts as a modulator of host cytokine production and regulator of effector protein translocation $[28,29]$. Though F1 protein was observed by mass spectrometry in Nanotrap samples, it was not found to be enriched through western blotting (Additional file 1: Figure S5). Following 1:4, $1: 40$, and 1:400 dilutions of bacterial supernatant in DPBS or 1:4 diluted whole human blood, $1 \mathrm{~mL}$ samples were incubated with CN3080 Nanotraps for $2 \mathrm{~h}$ at $4{ }^{\circ} \mathrm{C}$. LcrV (V-antigen) was detected by mass spectrometry (Additional file 1: Figure S7) and Western-blot bands could be detected at a greater intensity in the Nanotrap sample than in the corresponding control samples (Fig. 5a). We were unable to detect protein at the 1:40 dilution without use of Nanotraps. However, the limit of detection was reached even with Nanotraps prior to the 1:400 dilution. Following CN3080 Nanotrap overnight incubation at $4{ }^{\circ} \mathrm{C}$ with undiluted bacterial secreted protein, we were successfully able to concentrate LcrV (Fig. 5b). LcrV exists at low levels in the cell prior to bacterial secretion and T3SS assembly. Using $0.5,1.0,5.0$, and $7.0 \mathrm{mg} / \mathrm{mL}$ Yersinia WCL, we were able to detect LcrV at our lowest concentration utilizing Nanotraps. The use of Nanotraps resulted in a 2.5 fold increase in band intensity from $1 \mathrm{mg} / \mathrm{mL}$ WCL and a fivefold increase from $0.5 \mathrm{mg} / \mathrm{mL}$ (Fig. $5 \mathrm{c}$, d). However, at higher concentrations of $\mathrm{V}$-antigen, the utility of Nanotraps decreased, consistent with prior reports. These data indicate that CN3080 Nanotrap enables the detection of $\mathrm{V}$-antigen in blood and in bacterial lysates when it is present at low levels.

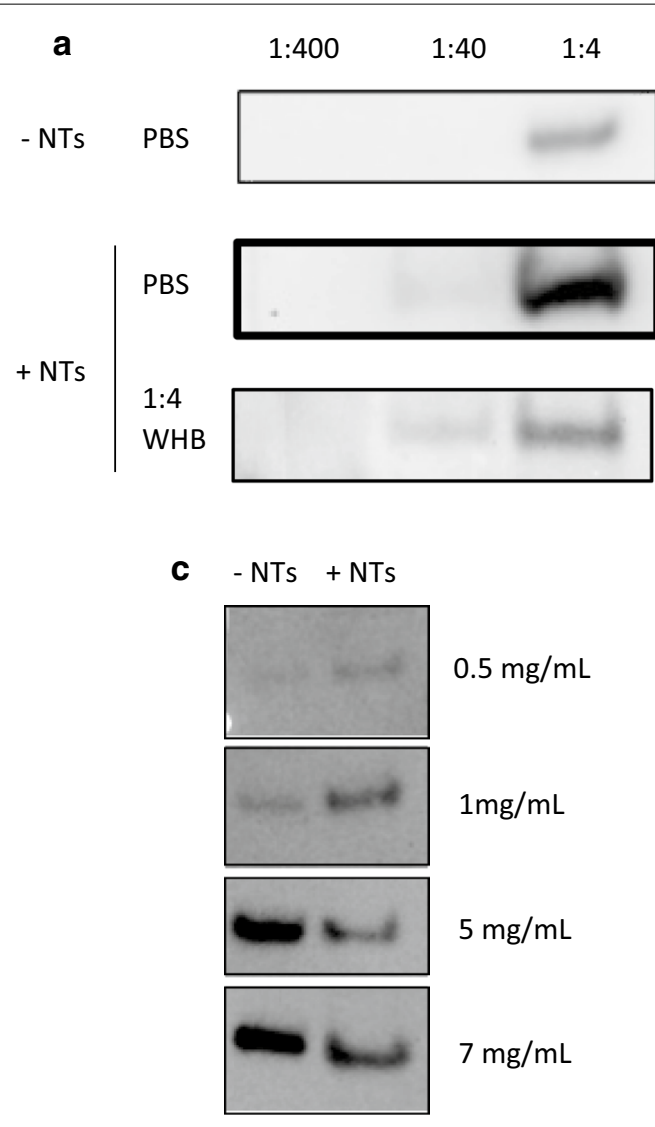

b

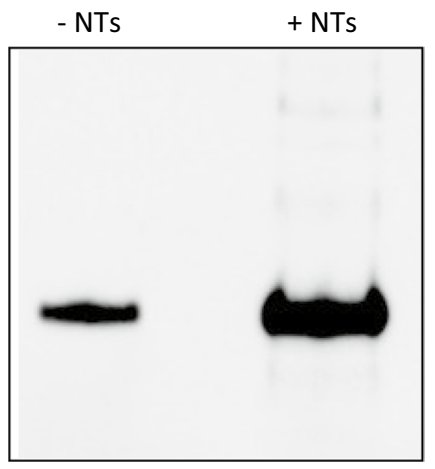

d

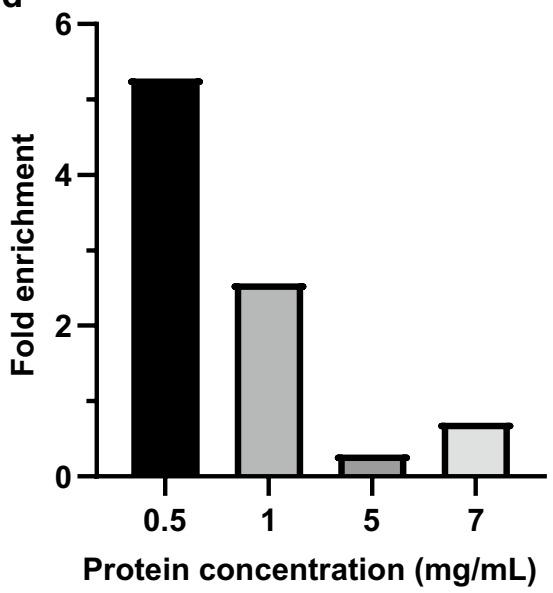

Fig. 5 CN3080 Nanotraps bind Yersinia V-antigen in whole human blood. a V-antigen western blot of 1:4, 1:40, 1:400 dilutions of Yersinia supernatant in diluted human blood or PBS without (top) and with CN3080s (middle, bottom). b CN3080s effectively concentrate V-antigen from bacterial supernatant. $\mathbf{c}, \mathbf{d}$ Fold enrichment of protein concentration is greater at lower initial protein concentrations 


\section{CN3080 Reactive Red 120 dye binds virulence factors LcrV and PsaA}

In order to gain insight on how CN3080 Nanotrap may interact with Yersinia pestis proteins, we performed computational protein docking of Yersinia pestis proteins against the Reactive Red 120 dye which is in the CN3080 Nanotrap particles. We selected LcrV and pH 6 antigen (PsaA) proteins given their elevated enrichment values found by mass spectrometry and the high degree of association with Nanotraps as visualized by western blotting.

PsaA is a $17 \mathrm{kDa}$ protein known for its role as a fibrillar component expressed following engulfment by macrophages. It is exclusively expressed at $37{ }^{\circ} \mathrm{C}$ and acts as an obligate virulence factor. PsaA directly interacts with the human TRAF-type zinc finger domain-containing protein 1, and functions as an inhibitor of phagocytosis and promoter of host cell adherence. Because we consistently found this protein with elevated enrichment scores $(2.80,1.16,2.11)$ within our $37{ }^{\circ} \mathrm{C}$ sample, we sought to visualize docking through modeling of this protein's interaction with Reactive Red 120, the dye in CN3080 particles (Fig. 6a). SwissDock modeling was performed using the PDB structures for the proteins and the dye to predict the sites of interaction of this protein with the dye included in the CN3080 Nanotrap. The strongest $\Delta \mathrm{G}$ value was -10.0072 (Fig. 6c), suggesting a high level of affinity between this protein and Reactive Red 120. Multiple docking predictions were reported, with the majority of those found to be located near the C-terminal, suggesting that there may be multiple opportunities for this protein to be bound by the Reactive Red 120 dye molecule. This may explain the high levels of Nanotrap enrichment of this protein observed in our study.

As mentioned above, LcrV is a multifunctional virulence factor known for its roles in modulation of immune response and regulation of effector protein secretion in Yesinia pestis. LcrV expression is induced by temperature shift to $37{ }^{\circ} \mathrm{C}$ [27]. It is highly expressed in the $37{ }^{\circ} \mathrm{C}$ samples and is required for full virulence. LcrV is enriched in the $37{ }^{\circ} \mathrm{C}$ agar-grown whole bacterial lysate + Nanotrap samples by both mass spectrometry and western blotting. Based on our Swiss-Dock modeling of the interaction between LcrV and Reactive Red 120 (Fig. 6b), the dye in these Nanotraps, it has a very strong interaction with a $\Delta \mathrm{G}$ value of 11.59 (Fig. $6 \mathrm{~d}$ ), supporting our experimental findings of enrichment of LcrV protein by using Nanotraps.
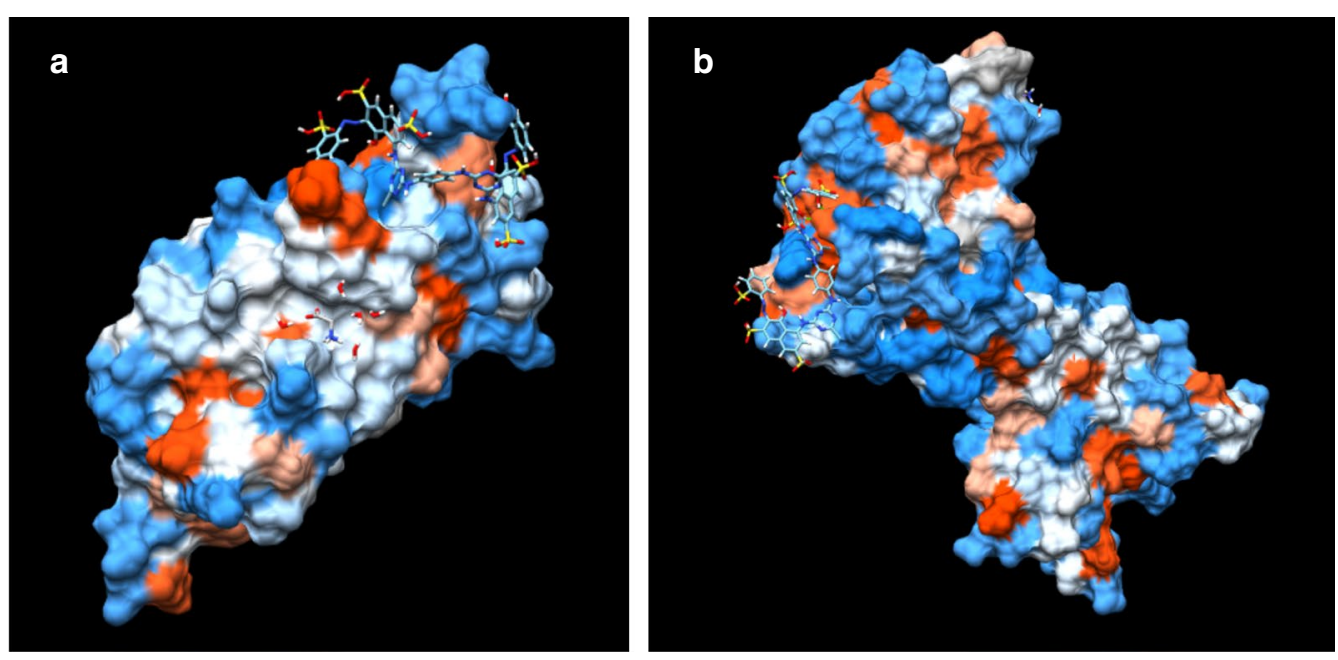

\begin{tabular}{|l|l|l|l|}
\hline \multicolumn{3}{|l|}{ C PsaA } & d LcrV \\
\hline Cluster serial \# & Estimated $\Delta \mathrm{G}(\mathrm{Kcal} / \mathrm{mol})$ & Cluster serial \# & Estimated $\Delta \mathrm{G}(\mathrm{Kcal} / \mathrm{mol})$ \\
\hline 8 & -10.01 & 4 & -11.59 \\
\hline 6 & -9.60 & 19 & -10.75 \\
\hline 2 & -9.54 & 31 & -10.49 \\
\hline 11 & -9.45 & 18 & -10.48 \\
\hline 0 & -9.44 & 0 & -10.25 \\
\hline
\end{tabular}

Fig. 6 Modeling of interaction between Reactive Red-120 Dye and Yersinia proteins. Predictive modeling show multiple sites of strong interaction for Reactive Red (RR)-120 Dye with Yersinia pestis proteins PsaA and LcrV. a PsaA, b LcrV, c Estimated $\triangle G$ (Kcal/mol) for top PsaA-RR120 dye interactions. d Estimated $\triangle \mathrm{G}(\mathrm{Kcal} / \mathrm{mol})$ for top LcrV-RR120 dye interactions 
In further analysis, the active sites of PsaA and LcrV were highlighted; one for galactose-binding site (PsaA) [31] and the other for TLR2 interaction region (LcrV) [32] (Additional file 1: Figure S8A, B). The strongest binding sites of Reactive Red 120 were exactly correlated to these active sites. Also, the major interactions were shown to be hydrogen bonds (Additional file 1: Figure S8C, D, E), between active sites of LcrV and Reactive Red 120. In Figures S8A and S8B, these sites were labeled with distances of $\mathrm{H}$-bonds which were plotted next to the highlighted graph.
Thus, the computational modeling supports the strong interaction of LcrV with the Reactive Red dye which is a component of the CN3080 Nanotrap, and thus may in part explain the enrichment of LcrV observed with the CN3080 Nanotrap observed in our experiments.

\section{CN3080 Nanotraps bind Yersinia pestis virulence factors}

We have shown that the Nanotrap particles enhance the mass-spectrometry based detection of multiple Yersinia virulence factors, including the well-known protein antigens F1 and LcrV (Fig. 7). Surface proteins such as F1 antigen (caf1) and F1 chaperone protein Caf1M showed

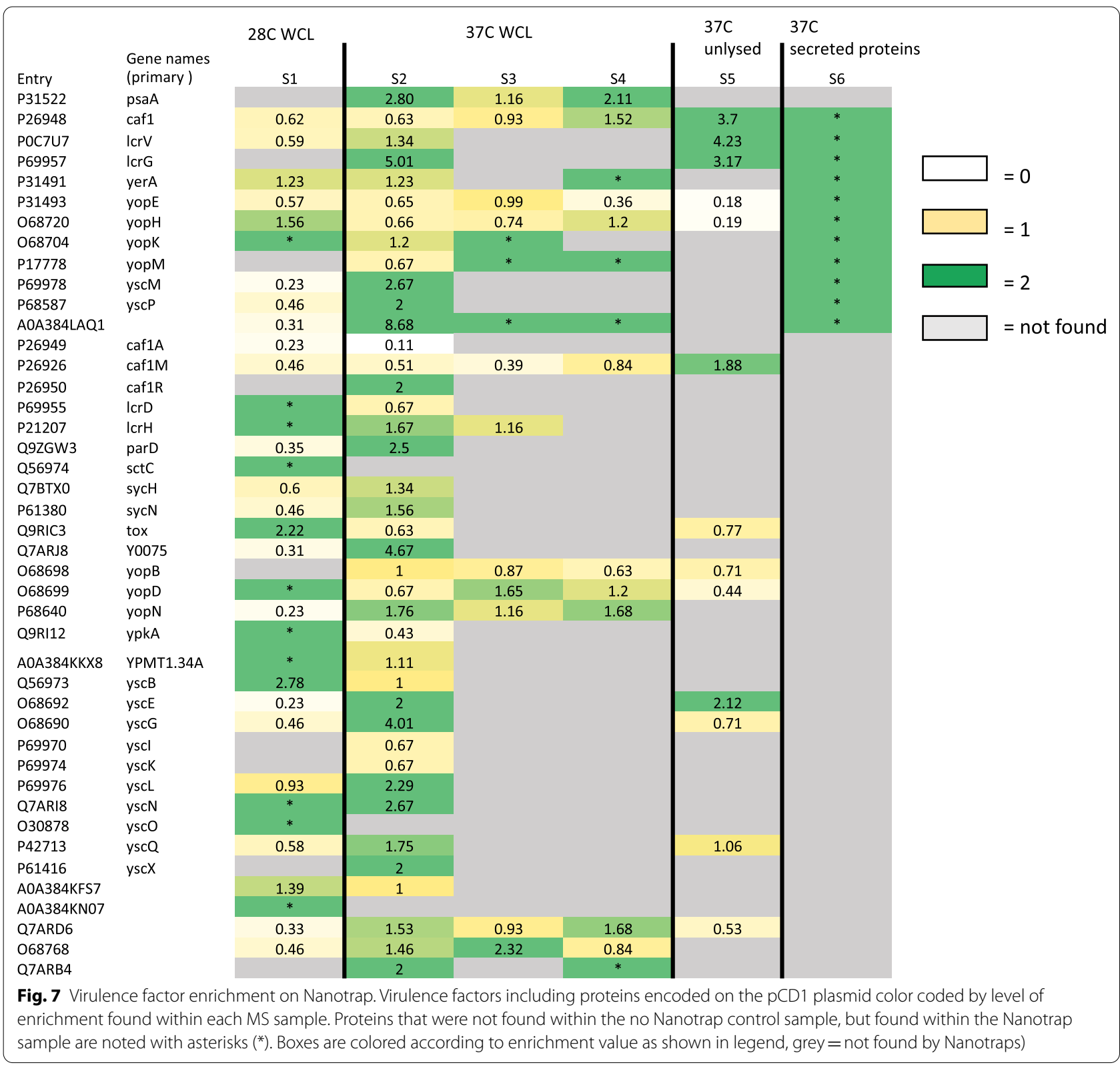


higher levels of enrichment on CN3080 Nanotraps within whole bacteria bound to CN3080 Nanotraps, (Sample 5 , see sample key in Table 1), relative to $37^{\circ} \mathrm{C}$ whole cell lysate (WCL) samples (Samples 2, 3 and 4, Table 1). This may indicate more effective surface protein binding when Nanotraps are exposed to whole cells as opposed to entire lysed cell contents. Conversely, LcrG showed high affinity ( fivefold) to Nanotraps in WCL lysate from agar-grown $Y$. pestis grown at $37^{\circ} \mathrm{C}$ (Sample 2), but was not found on Nanotraps incubated with WCL lysate of $Y$. pestis grown at $28^{\circ} \mathrm{C}$ (Sample 1) or in broth-grown bacterial cells grown at $37^{\circ} \mathrm{C}$ (Samples 3,4$)$.

The $Y$. pestis T3SS is comprised of over 20 proteins, each capable of forming both stable and transient interactions with other Yersinia and host proteins [33]. We have found multiple of these components at higher rates in Nanotrap (CN3080) samples (Fig. 8). Identifying these T3SS proteins and other virulence factors provides us the opportunity to use these as potential future diagnostic markers.

Low calcium response (Lcr) proteins LcrD [33], LcrG [34, 35], LcrH [36, 37], and LcrV were found prominently within Nanotrap samples in both $28^{\circ} \mathrm{C}$ and $37^{\circ} \mathrm{C}$ grown WCL samples. Notably LcrG and LcrV were found in many Nanotrap samples, and LcrG was enriched from samples grown at $37^{\circ} \mathrm{C}$ with the use of Nanotraps. T3SS chaperone protein LcrG acts as a regulator of LcrV secretion and exists as both a cytoplasmic and secreted protein. Given the known binding of LcrV and LcrG and their elevated enrichment scores in some sample types may suggest Nanotrap binding of the LcrGV complex.

Four of the six translocated Yop effectors (YopE, YopH, YpkA, and YopM) [38] were found associated with the CN3080 Nanotraps, although were not found to be enriched. Other Yop proteins such as YopB, YopD, YopK, and YopN were also found within Nanotrap samples. YopB and YopD effectors are outer pore-forming proteins acting in conjunction with LcrV to form the translocon [39]. Though YopB and YopD were present in Nanotraps samples, they were not found to be significantly enriched.

Additionally, several interacting pairs of proteins were found to both be enriched, such as putative toxin-antitoxin proteins ParD and Y0075 (ParE). Our data support higher enrichment scores for some chaperone proteins pulled from $37^{\circ} \mathrm{C}$ cell lysate (Additional file 1: Figure S6); for example, we found T3SS chaperones SycH and SycE,

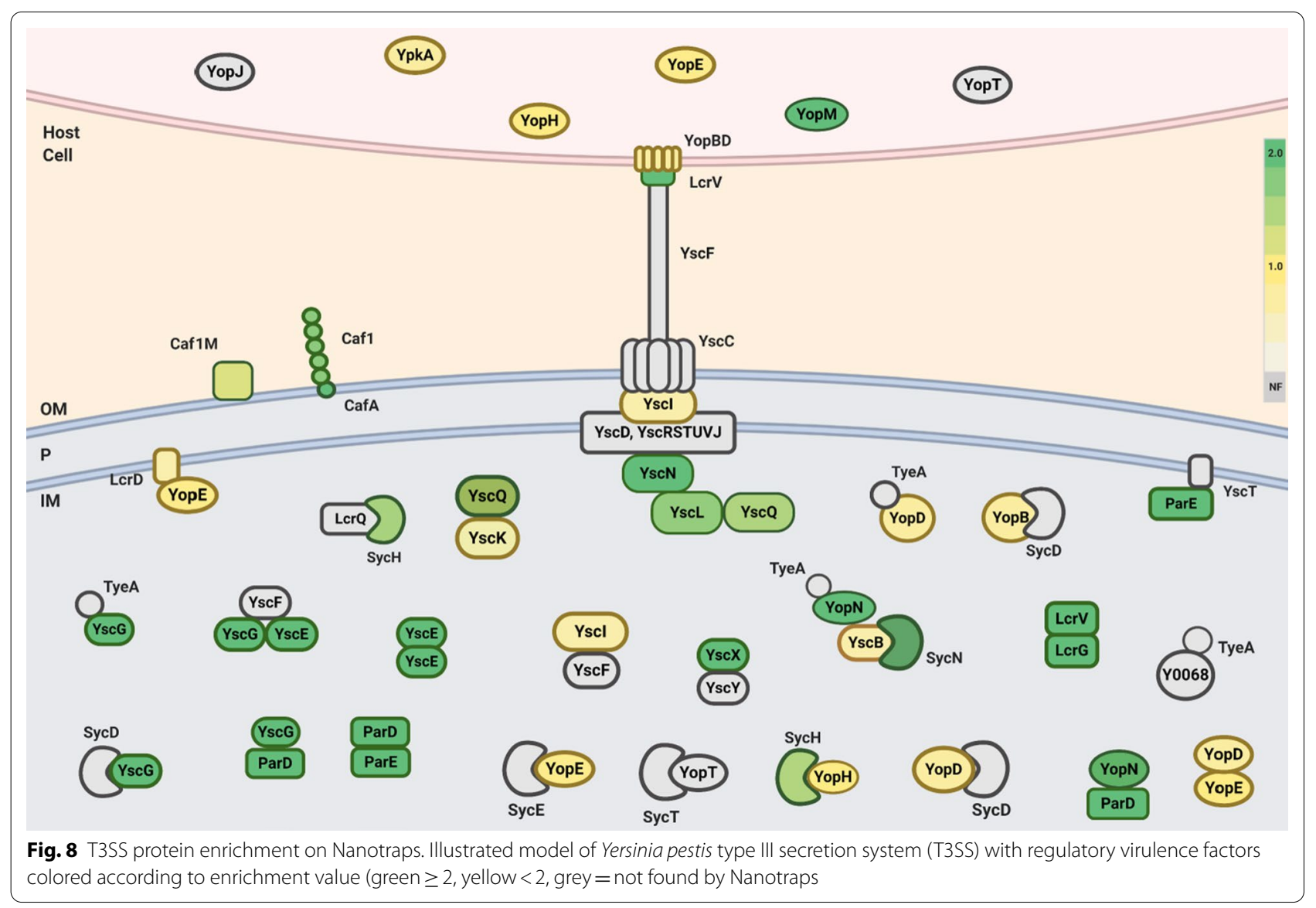


while others were not found within our data set. We identified structural components of the injectosome such as YopBD, LcrV, YscI, YscL, and YscQ associated with Nanotraps; however, we were unable to find either of the intermembrane rings or the YscF needle. We found high (>2) enrichment scores for YscN, YscL, and LcrV. In this work, LcrV has been shown to be enriched by CN3080 Nanotraps through both mass spectrometry and western blotting, especially in unlysed cells and supernatant.

\section{Discussion}

Here, we characterized the ability of Nanotrap particles (type CN3080) to bind Yersinia pestis bacteria, proteins, and nucleic acids. We found that the bacteria associate tightly with the Nanotraps, even after washing. We were able to observe the interaction of the bacteria with the Nanotraps by electron microscopy. Experiments showed enhanced nucleic acid yield with the use of Nanotraps. CN3080 Nanotraps effectively concentrated many Yersinia proteins for MS detection and allowed visualization of LcrV from blood samples. The magnetic property of these particles made the process more rapid and facilitated the workflow. The large, planar dye molecule that is the affinity bait has relatively non-specific binding properties, and thus can sample a wide variety of biomarkers, which can enhance the detection of low abundance biomarkers [14-16]. It is not known what functional moieties on the bacterial surface participate in this interaction with the Nanotraps, although some outer membrane proteins were identified as binding the Nanotraps.

As plating is the gold standard for Yersinia pestis diagnosis, we sought to determine the affinity that CN3080 Nanotraps have for intact bacteria in whole human blood. We found that the Nanotraps have the capacity to bind to a significant number of Yersinia pestis bacteria, and that this binding was stable with repeated washings. However, the Nanotraps are unable to bind to all of the bacteria in the sample and cannot "clear" the sample of bacteria, so they are useful for downstream processing but not for quantitative measure or removal of Yersinia bacteria.

The circumstances under which free Yersinia pestis nucleic acid might be present in blood or plasma samples may be as a result of bacterial cell death and release of their nucleic acid through other mechanisms. The CN3080 Nanotraps were shown to be quite effective at binding Yersinia nucleic acids in biological matrices such as whole human blood. Nanotraps might be useful to enrich nucleic acids in upstream steps of a workflow that involves complex biological matrices such as clinical samples. Because secondary verification is necessary for appropriate diagnosis, the use of CN3080 Nanotraps may prove beneficial for early detection and help expedite diagnosis.

While the binding capacity of the particles is not highly specific (rather it provides a "sampling" of the biomarkers present) and can be affected by the biological matrix (whole blood vs. plasma vs. PBS, for example), we found overall that a wide range of Yersinia pestis proteins could be found associated with the Nanotrap CN3080 particles. Due to the nature of the Nanotrap dye baits, this interaction is likely to be relatively non-specific, representing the sum of interaction between the bacteria and the magnetic and hydrogel material of the particle as well as with the dye-bait enclosed within the particle. This generally "non-specific" binding can be an advantage to using the Nanotrap particles, as it does not preclude broader binding capacity compared to an antibody-decorated particle for example, and allows wide "sampling" of the proteins in the sample. Different Nanotrap formulations may bind a different profile of proteins, thus broadening the sampling of any particular sample $[15,16,40]$.

We found that the Nanotrap particles enhance the mass-spectrometry based detection of Yersinia proteins, including the well-known protein antigens F1 and LcrV, as well as PsaA. Nanotraps may be useful as an additional research tool for investigational purposes, as shown by the ability to concentrate secreted proteins and "clean up" a protein sample from whole blood prior to western blotting.

The Yersinia pestis $\mathrm{V}$ antigen (LcrV) is a multifunctional virulence factor, responsible for regulating the translocation of its cytotoxic effector proteins into host eukaryotic cells through a type III secretion system (T3SS). Due to the protein's immunosuppressive qualities and effective neutralization through antibody treatment, LcrV has been a target for vaccine development $[28,29,41]$. The Fraction 1 antigen (F1) acts as an antiphagocytic barrier expressed on the outside of the bacterium during mammalian infection [42]. These F1 polymers are released from bacterial cells and shed into the system of the host, acting as a definitive marker of $Y$. pestis infection. F1 has been shown to give anti-plague immunity in animal models against pneumonic and bubonic forms [42]. The identification of LcrV and F1 bound to Nanotraps suggests that Nanotraps may be a useful upstream enhancement to a workflow that may detect these antigens such as lateral flow assays, or other protein based detection methods. The F1 and LcrV antigens are currently used as a diagnostic marker in dipstick, lateral flow and other clinical approaches [43-45]. Thus, Nanotraps could potentially enhance the sensitivity of such diagnostic tools. In addition, the Nanotraps can enhance detection of lowabundance proteins such as secreted proteins. 
We characterized the ability of CN3080 Nanotrap particles to bind Yersinia pestis intact bacteria, proteins, as well as nucleic acids. Nanotraps may thus provide a useful new upstream sample-processing step to enhance the detection and diagnosis of Yersinia pestis in human plasma and whole blood, which are clinically relevant samples. This approach can enhance molecular assays such as PCR-based methods or protein-based methods such as Western Blotting. The integration of Nanotraps into a blood collection device could provide a useful technical improvement of the ability to bind and detect these Yersinia analytes.

\section{Supplementary Information}

The online version contains supplementary material available at https://doi. org/10.1186/s12951-021-00859-8.

\section{Additional file 1: Additional Figure S1 to S8.}

Additional file 2: Table S1. Mass spectrometry data from whole cell lysate of Yersinia pestis grown on $\mathrm{BHI}$ agar at $28^{\circ} \mathrm{C}$ bound to Nanotraps (CN3080s), Sample 1. ${ }^{*}=$ not found in control sample; Grey $=$ the \#PSMs do not reach enrichment calculation threshold.

Additional file 3: Table S2. Mass spectrometry data from whole cell lysate of Yersinia pestis grown on $\mathrm{BHI}$ agar at $37^{\circ} \mathrm{C}$ bound to Nanotraps (CN3080s), Sample $2 .{ }^{*}=$ not found in control sample; Grey= the \#PSMs do not reach enrichment calculation threshold.

Additional file 4: Table S3. Mass spectrometry data from whole cell lysate of Yersinia pestis grown in $\mathrm{BHI}$ broth at $37^{\circ} \mathrm{C}$ bound to Nanotraps (CN3080s), Sample 3. *not found in control sample; Grey = the \#PSMs do not reach enrichment calculation threshold.

Additional file 5: Table S4. Mass spectrometry data from whole cell lysate of Yersinia pestis grown in $\mathrm{BHI}$ broth at $37^{\circ} \mathrm{C}$ bound to Nanotraps (CN3080s) and washed with DPBS, Sample 4. * not found in control sample; Grey = the \#PSMs do not rea enrichment calculation threshold.

Additional file 6: Table S5. Mass spectrometry data from intact, whole Yersinia pestis bacteria grown in $\mathrm{BHI}$ at $37^{\circ} \mathrm{C}$ bound to Nanotraps (CN3080s), Sample $5 .{ }^{*}=$ not found in control sample; Grey $=$ the \#PSMs do not reach enrichment calculation threshold.

Additional file 7: Table S6. Mass spectrometry data from cell supernatant (secreted proteins) of Yersinia pestis grown in $\mathrm{BHI}$ at $37^{\circ} \mathrm{C}$ bound to Nanotraps (CN3080s), Sample 6. ${ }^{*}=$ not found in control sample.

Additional file 8: Table S7. Panther Overrepresentation Test using proteins with greater than 2.0 enrichment score from sample W37A. Sheet 1: Biological processes, Sheet 2: Molecular function, Sheet 3: Cellular component.

\section{Acknowledgements}

The authors thank Erwin Berthier and Emily Welch, Tasso Inc, for helpful discussions and Ramin Hakami, GMU, and Rekha Panchal, USAMRIID, for the Y. pestis pst-pgm- strain. We are grateful to Dr. Amy Smith, GMU, for assistance implementing SwissDock and to Dr. Shan-Meng Lin at National Chung Hsing University, Taiwan for further support with the docking analysis.

\section{Authors' contributions}

$\mathrm{ANI}$ and MLVH designed the experiments and wrote the manuscript. ANI conducted the experiments, statistical analysis, and data interpretation. WZ contributed mass spectrometry data collection and data interpretation methodology. SCL provided computational prediction of Reactive red binding sites. $\mathrm{BL}$ and $\mathrm{KKH}$ contributed to writing and assisted in editing the manuscript. All authors read and approved the final manuscript.

\section{Funding}

This work was supported by a grant from Defense Threat Reduction Agency (DTRA) grant, HDTRA1-17-C-0069, to Tasso, Inc with a subcontract to KKH and $\mathrm{MvH}$. DTRA does not have any role in the design of the study and collection, analysis, and interpretation of data and nor in writing the manuscript.

\section{Availability of data and materials}

All data and materials are available within the manuscript and in additional files.

\section{Declarations}

Ethics approval and consent to participate

Not applicable.

\section{Consent for publication}

Not applicable.

\section{Competing interests}

$\mathrm{BL}$ is an employee of Ceres Nanosciences Inc. KKH is a member of Ceres' Scientific Advisory Board. ANI, MvH, SCL, and WZ declare no competing interests.

\section{Author details}

'School of Systems Biology, George Mason University, Manassas, VA 20110, USA. ${ }^{2}$ Present Address: College of Life Sciences, National Taiwan Ocean University, 2 Pei-Ning Rd, Keelung 202301, Taiwan. ${ }^{3}$ Ceres Nanosciences, 9460 Innovation Drive, Manassas, VA 20110, USA. ${ }^{4}$ Center for Applied Proteomics and Personalized Medicine, George Mason University, Manassas, VA 20110, USA. ${ }^{5}$ Present Address: Department of Biomedical Sciences and Pathobiology, Virginia Polytechnic Institute and State University, Blacksburg, VA 24060, USA.

Received: 20 January 2021 Accepted: 9 April 2021

Published online: 21 June 2021

\section{References}

1. Yang R. Plague: recognition, treatment, and prevention. J Clin Microbiol. 2018;56:e01519.

2. Andrianaivoarimanana $\mathrm{V}$, Piola P, Wagner DM, Rakotomanana F, Maheriniaina V, Andrianalimanana S, Chanteau S, Rahalison L, Ratsitorahina M, Rajerison M. Trends of human plague, Madagascar, 1998-2016. Emerg Infect Dis. 2019;25:220-8.

3. Inglesby TV, Dennis DT, Henderson DA, Bartlett JG, Ascher MS, Eitzen E, Fine AD, Friedlander AM, Hauer J, Koerner JF, et al. Plague as a biological weapon: medical and public health management Working Group on Civilian Biodefense. JAMA. 2000;283:2281-90.

4. Bi Y. Immunology of Yersinia pestis infection. Adv Exp Med Biol. 2016;918:273-92

5. Aloni-Grinstein R, Schuster O, Yitzhaki S, Aftalion M, Maoz S, SteinbergerLevy I, Ber R. Isolation of Francisella tularensis and Yersinia pestis from blood cultures by plasma purification and immunomagnetic separation accelerates antibiotic susceptibility determination. Front Microbiol. 2017;8:312.

6. Shafagati N, Narayanan A, Baer A, Fite K, Pinkham C, Bailey C, Kashanchi F, Lepene B, Kehn-Hall K. The use of NanoTrap particles as a sample enrichment method to enhance the detection of Rift Valley Fever Virus. PLoS Negl Trop Dis. 2013;7:e2296.

7. Jaworski E, Saifuddin M, Sampey G, Shafagati N, Van Duyne R, lordanskiy S, Kehn-Hall K, Liotta L, Petricoin E 3rd, Young M, et al. The use of Nanotrap particles technology in capturing HIV-1 virions and viral proteins from infected cells. PLOS ONE. 2014;9:e96778.

8. Shafagati N, Patanarut A, Luchini A, Lundberg L, Bailey C, Petricoin E 3rd, Liotta L, Narayanan A, Lepene B, Kehn-Hall K. The use of Nanotrap particles for biodefense and emerging infectious disease diagnostics. Pathog Dis. 2014;71:164-76.

9. Magni R, Espina BH, Shah K, Lepene B, Mayuga C, Douglas TA, Espina V, Rucker S, Dunlap R, Petricoin EF, et al. Application of Nanotrap technology for high sensitivity measurement of urinary outer surface protein A 
carboxyl-terminus domain in early stage Lyme borreliosis. J Transl Med. 2015;13:346.

10. Shafagati N, Lundberg L, Baer A, Patanarut A, Fite K, Lepene B, Kehn-Hall $K$. The use of nanotrap particles in the enhanced detection of Rift Valley fever virus nucleoprotein. PLOS ONE. 2015;10:e0128215.

11. Shafagati N, Fite K, Patanarut A, Baer A, Pinkham C, An S, Foote B, Lepene $B$, Kehn-Hall K. Enhanced detection of respiratory pathogens with nanotrap particles. Virulence. 2016;7:756-69.

12. Akhrymuk I, Lin SC, Sun M, Patnaik A, Lehman C, Altamura L, Minogue T, Lepene B, van Hoek ML, Kehn-Hall K. Magnetic nanotrap particles preserve the stability of Venezuelan Equine Encephalitis Virus in blood for laboratory detection. Front Vet Sci. 2019;6:509.

13. Lin SC, Carey BD, Callahan V, Lee JH, Bracci N, Patnaik A, Smith AK, Narayanan A, Lepene B, Kehn-Hall K. Use of Nanotrap particles for the capture and enrichment of Zika, chikungunya and dengue viruses in urine. PLoS ONE. 2020;15:e0227058

14. Tamburro D, Fredolini C, Espina V, Douglas TA, Ranganathan A, llag L, Zhou W, Russo P, Espina BH, Muto G, et al. Multifunctional core-shell nanoparticles: discovery of previously invisible biomarkers. J Am Chem Soc. 2011;133:19178-88.

15. Longo C, Patanarut A, George T, Bishop B, Zhou W, Fredolini C, Ross MM, Espina V, Pellacani G, Petricoin EF 3rd, et al. Core-shell hydrogel particles harvest, concentrate and preserve labile low abundance biomarkers. PLOS ONE. 2009:4:e4763.

16. Fredolini C, Meani F, Reeder KA, Rucker S, Patanarut A, Botterell PJ, Bishop $\mathrm{B}$, Longo C, Espina V, Petricoin EF 3rd, et al. Concentration and preservation of very low abundance biomarkers in urine, such as human growth hormone (hGH), by Cibacron Blue F3G-A loaded hydrogel particles. Nano Res. 2008;1:502-18.

17. Bhaisare ML, Abdelhamid HN, WU BS, Wu HF. Rapid and direct MALDI-MS identification of pathogenic bacteria from blood using ionic liquidmodified magnetic nanoparticles (Fe3O4@SiO2). J Mater Chem B. 2014:2:4671-83.

18. Abdelhamid HN, Wu HF. Multifunctional graphene magnetic nanosheet decorated with chitosan for highly sensitive detection of pathogenic bacteria. J Mater Chem B. 2013;1:3950-61.

19. Hasan N, Guo Z, Wu HF. Large protein analysis of Staphylococcus aureus and Escherichia coli by MALDI TOF mass spectrometry using amoxicillin functionalized magnetic nanoparticles. Anal Bioanal Chem. 2016:408:6269-81.

20. Paris L, Magni R, Zaidi F, Araujo R, Saini N, Harpole M, Coronel J, Kirwan $\mathrm{DE}$, Steinberg $\mathrm{H}$, Gilman RH, et al. Urine lipoarabinomannan glycan in HIVnegative patients with pulmonary tuberculosis correlates with disease severity. Sci Transl Med. 2017;9:eaal2807.

21. Welkos S, Pitt ML, Martinez M, Friedlander A, Vogel P, Tammariello R. Determination of the virulence of the pigmentation-deficient and pigmentation-/plasminogen activator-deficient strains of Yersinia pestis in non-human primate and mouse models of pneumonic plague. Vaccine. 2002;20:2206-14.

22. Jenkins AL, Worsham PL, Welkos SL. A strategy to verify the absence of the pgm locus in Yersinia pestis strain candidates for select agent exemption. J Microbiol Methods. 2009;77:316-9.

23. Kota KP, Eaton B, Lane D, Ulrich M, Ulrich R, Peyser BD, Robinson CG, Jaissle JG, Pegoraro G, Bavari S, Panchal RG. Integrating high-content imaging and chemical genetics to probe host cellular pathways critical for Yersinia pestis infection. PLoS ONE. 2013;8:e55167.

24. Flashner Y, Mamroud E, Tidhar A, Ber R, Aftalion M, Gur D, Lazar S, Zvi A, Bino T, Ariel N, et al. Generation of Yersinia pestis attenuated strains by signature-tagged mutagenesis in search of novel vaccine candidates. Infect Immun. 2004;72:908-15.

25. Hao H, Liang J, Duan R, Chen Y, Liu C, Xiao Y, Li X, Su M, Jing H, Wang X. Yersinia spp. identification using copy diversity in the chromosomal 165 rRNA gene sequence. PLoS ONE. 2016;11:e0147639.

26. Kaláb M, Yang A, Chabot D. Conventional scanning electron microscopy of bacteria. Focus Mag. 2008;10:42-61.

27. Yother J, Chamness TW, Goguen JD. Temperature-controlled plasmid regulon associated with low calcium response in Yersinia pestis. J Bacteriol. 1986;165:443-7.
28. Philipovskiy AV, Cowan C, Wulff-Strobel CR, Burnett SH, Kerschen EJ, Cohen DA, Kaplan AM, Straley SC. Antibody against $V$ antigen prevents Yop-dependent growth of Yersinia pestis. Infect Immun. 2005;73:1532-42.

29. Derewenda U, Mateja A, Devedjiev Y, Routzahn KM, Evdokimov AG, Derewenda ZS, Waugh DS. The structure of Yersinia pestis V-antigen, an essential virulence factor and mediator of immunity against plague. Structure. 2004;12:301-6.

30. Du Y, Rosqvist R, Forsberg A. Role of fraction 1 antigen of Yersinia pestis in inhibition of phagocytosis. Infect Immun. 2002;70:1453-60.

31. Bao R, Nair MK, Tang WK, Esser L, Sadhukhan A, Holland RL, Xia D, Schifferli DM. Structural basis for the specific recognition of dual receptors by the homopolymeric $\mathrm{pH} 6$ antigen (Psa) fimbriae of Yersinia pestis. Proc Natl Acad Sci U S A. 2013;110:1065-70.

32. Wei T, Gong J, Qu G, Wang M, Xu H. Interactions between Yersinia pestis V-antigen (LCrV) and human Toll-like receptor 2 (TLR2) in a modelled protein complex and potential mechanistic insights. BMC Immunol. 2019;20:48.

33. Yang $H$, Tan $Y$, Zhang $T$, Tang L, Wang J, Ke Y, Guo Z, Yang $X$, Yang R, Du Z Identification of novel protein-protein interactions of Yersinia pestis type III secretion system by yeast two hybrid system. PLoS ONE. 2013;8:e54121.

34. Chaudhury S, de Azevedo SC, Plano GV, De Guzman RN. The LcrG Tip chaperone protein of the Yersinia pestis type III secretion system is partially folded. J Mol Biol. 2015;427:3096-109.

35. Reina LD, O'Bryant DM, Matson JS, Nilles ML. LcrG secretion is not required for blocking of Yops secretion in Yersinia pestis. BMC Microbiol. 2008:8:29.

36. Francis MS, Aili M, Wiklund ML, Wolf-Watz H. A study of the YopD-IcrH interaction from Yersinia pseudotuberculosis reveals a role for hydrophobic residues within the amphipathic domain of YopD. Mol Microbiol. 2000;38:85-102.

37. Singh SK, Boyle AL, Main ER. LCrH, a class II chaperone from the type three secretion system, has a highly flexible native structure. J Biol Chem. 2013:288:4048-55.

38. Pha K, Navarro L. Yersinia type III effectors perturb host innate immune responses. World J Biol Chem. 2016;7:1-13.

39. Holmstrom A, Olsson J, Cherepanov P, Maier E, Nordfelth R, Pettersson J, Benz R, Wolf-Watz H, Forsberg A. LcrV is a channel size-determining component of the Yop effector translocon of Yersinia. Mol Microbiol. 2001;39:620-32.

40. Luchini A, Geho DH, Bishop B, Tran D, Xia C, Dufour RL, Jones CD, Espina $\checkmark$, Patanarut A, Zhou W, et al. Smart hydrogel particles: biomarker harvesting: one-step affinity purification, size exclusion, and protection against degradation. Nano Lett. 2008;8:350-61.

41. Fields KA, Nilles ML, Cowan C, Straley SC. Virulence role of V antigen of Yersinia pestis at the bacterial surface. Infect Immun. 1999;67:5395-408.

42. Levy Y, Vagima Y, Tidhar A, Aftalion M, Gur D, Nili U, Chitlaru T, Zauberman A, Mamroud E. Targeting of the Yersinia pestis F1 capsular antigen by innate-like B1b cells mediates a rapid protective response against bubonic plaque. NPJ Vaccines. 2018;3:52.

43. Gomes-Solecki MJ, Savitt AG, Rowehl R, Glass JD, Bliska JB, Dattwyler RJ. LcrV capture enzyme-linked immunosorbent assay for detection of Yersinia pestis from human samples. Clin Diagn Lab Immunol. 2005;12:339-46.

44. Hong W, Huang L, Wang H, Qu J, Guo Z, Xie C, Zhu Z, Zhang Y, Du Z, Yan $Y$, et al. Development of an up-converting phosphor technology-based 10-channel lateral flow assay for profiling antibodies against Yersinia pestis. J Microbiol Methods. 2010;83:133-40.

45. Hsu HL, Chuang CC, Liang CC, Chiao DJ, Wu HL, Wu YP, Lin FP, Shyu RH. Rapid and sensitive detection of Yersinia pestis by lateral-flow assay in simulated clinical samples. BMC Infect Dis. 2018;18:402.

\section{Publisher's Note}

Springer Nature remains neutral with regard to jurisdictional claims in published maps and institutional affiliations. 